\title{
ClC3 Is a Critical Regulator of the Cell Cycle in Normal and Malignant Glial Cells
}

\author{
Christa W. Habela, Michelle L. Olsen, and Harald Sontheimer \\ Department of Neurobiology, Center for Glial Biology in Medicine, University of Alabama at Birmingham, Birmingham, Alabama 35294
}

\begin{abstract}
Although most brain cells are postmitotic, small populations of progenitor or stem cells can divide throughout life. These cells are believed to be the most likely source for primary brain malignancies including gliomas. Such tumors share many common features with nonmalignant glial cells but, because of their insidious growth, form cancers that are typically incurable. In studying the growth regulation of these tumors, we recently discovered that glioma cell division is preceded by a cytoplasmic condensation that we called premitotic condensation (PMC). PMC represents an obligatory step in cell replication and is linked to chromatin condensation. If perturbed, the time required to complete a division is significantly prolonged. We now show that PMC is a feature shared more commonly among normal and malignant cells and that the reduction of cell volume is accomplished by $\mathrm{Cl}^{-}$efflux through $\mathrm{ClC}_{3} \mathrm{Cl}^{-}$channels. Patch-clamp electrophysiology demonstrated a significant upregulation of chloride currents at $\mathrm{M}$ phase of the cell cycle. Colocalization studies and coimmunoprecipitation experiments showed the channel on the plasma membrane and at the mitotic spindle. To demonstrate a mechanistic role for ClC3 in PMC, we knocked down ClC3 expression using short hairpin RNA constructs. This resulted in a significant reduction of chloride currents at $\mathrm{M}$ phase that was associated with a decrease in the rate of $\mathrm{PMC}$ and a similar impairment of DNA condensation. These data suggest that $\mathrm{PMC}$ is an integral part of cell division and is dependent on $\mathrm{ClC} 3$ channel function.
\end{abstract}

Key words: voltage-gated chloride channels; mitosis; glioma; tubulin; premitotic condensation; DNA condensation

\section{Introduction}

In contrast to most other mammalian cell types, adult neural cells have traditionally been thought of as nonregenerative cells. Over the past 20 years, however, our understanding of the reality, importance, and consequences of postdevelopmental neural cell proliferation has undergone considerable revision. Adult neurogenesis is now widely accepted to have implications for most areas of neuroscience, including synaptic integration, neurodegeneration, injury, and epilepsy. In turn, neurogenesis is dependent on a resident population of cells in the brain that can be induced to proliferate in response to various stimuli. This has both positive and negative implications, and the most apparent pathology in which neural cell proliferation is a central mechanism of the disease process is brain tumors. Originally believed to be derived from astrocytes, there is now convincing genetic and functional evidence that gliomas, the predominant primary brain tumors, originate from neural stem cells (NSCs) (Oliver and Wechsler-Reya, 2004; Sanai et al., 2005; Fan et al., 2007), suggesting that these cell types may share common mechanisms of cell cycle regulation.

In dividing cells, the cell cycle is normally tightly regulated by a series of events that catalyze the transitions between G1, S, G2,

\footnotetext{
Received April 29, 2008; revised July 29, 2008; accepted Aug. 1, 2008.

This work was supported by National Institutes of Health Grants R01-NS031234, R01-NS036692, and P50CA97247. We thank Dr. William J. Hatton for kindly providing the CIC3 channel antibodies.

The authors declare no competing financial interests.

Correspondence should be addressed to Harald Sontheimer, 1719 6th Avenue South, CIRC 425, Birmingham, AL

35294. E-mail: sontheimer@uab.edu.

DOI:10.1523/JNEUROSCI.1897-08.2008

Copyright $\odot 2008$ Society for Neuroscience $\quad$ 0270-6474/08/289205-13\$15.00/0
}

and $\mathrm{M}$ phase. Ultimately, a successful cell division is dependent on the ability of the cell to distribute its genetic content between two daughter cells. This occurs along with the partitioning of the cytoplasmic content and the cell membrane. Both of these events require considerable structural changes, and adaptations in the biophysical characteristics of a cell may enhance its ability to effectively complete this process. Surprisingly little is known, however, about the biophysical aspects of neural cell proliferation. Although a number of studies have implicated ion channels in cell cycle progression in other cells, mechanistic causal relationships have been harder to establish. We recently reported an unexpected channel-mediated decrease in cytoplasmic volume, termed premitotic condensation (PMC), which occurs as glioma cells retract processes, round up, and progress through mitosis. We found that this process is linked to chromatin condensation and is energetically driven by the release of chloride through ion channels (Habela and Sontheimer, 2007). Because ion movement through channels is dictated by their electrochemical gradient, this outward movement suggests the accumulation of intracellular chloride $\left(\left[\mathrm{Cl}^{-}\right]_{\text {in }}\right)$ well above the concentration observed in postmitotic neurons and glial cells. Interestingly, this is analogous to the elevated $\left[\mathrm{Cl}^{-}\right]_{\text {in }}$ that is observed in NSCs during development and in the adult (Kakazu et al., 1999; Kuner and Augustine, 2000).

In this study, we show that PMC is a normal part of cell division in both normal and malignant glial cells and identify $\mathrm{ClC} 3$ as the $\mathrm{Cl}^{-}$efflux pathway in this process. ClC3 localizes to the plasma membrane and mitotic spindle and coimmunoprecipitates with tubulin. When ClC3 expression was knocked down using short hairpin RNA (shRNA) constructs, a significant re- 
duction of chloride currents at $\mathrm{M}$ phase associated with a decrease in the rate of PMC and a similar impairment of DNA condensation resulted. This demonstrates a novel, unexpected and significant role for $\mathrm{ClC} 3$ at division in proliferating astrocytes and glioma cells.

\section{Materials and Methods}

Glioma cell culture and pharmacology. D54-MG and U251-MG glioma cells (WHO IV, glioblastoma multiforme) were a gift from Dr. D. Bigner (Duke University, Durham, NC). The stable green fluorescent protein (GFP) cell line used for Figure $1 \mathrm{~A}$ was derived from D54-MG cells (D54-MG-GFP), which were transfected with peGFP-N1 (Clontech). The plasmid insertion was maintained with $0.25 \mathrm{mg} / \mathrm{ml} \mathrm{G} 418$ disulfate salt (Invitrogen). In all other experiments, the stable lines were generated by transfection with a $\mathrm{PGIPZ}$ vector (see below).

All glioma cells were maintained at $37^{\circ} \mathrm{C}, 10 \% \mathrm{CO}_{2}$ in 1:1 DMEM/F-12 (Mediatech) with 7\% FBS and $2 \mathrm{~mm}$ Gln and were used for experiments within the 20 passages. All stock concentrations of drugs used were dissolved in dimethylsulfoxide (DMSO). Unless otherwise noted, the DMSO stock was diluted 1:1000 to obtain the final working concentration. Drug treatment, media were composed of control media supplemented with DMSO or drugs dissolved in the same. 5-Nitro-2-(3phynylpropylamino)benzoic acid (NPPB) was used at $200 \mu \mathrm{m}$ for both two-dimensional (2D) time-lapse experiments and for electrophysiology. 4,4'-Diisothiocyanatostillbene-2,2' -disulfonic acid disodium salt hydrate (DIDS) was used at $200 \mu \mathrm{M}$. Unless otherwise stated, all reagents were purchased from Sigma.

Astrocyte cultures. Astrocytes were cultured from postnatal day 0 rat pups. Pups were anesthetized on ice and decapitated, and the spinal cords were dissected into ice-cold serum-free Eagles' minimum essential medium (EMEM) (Invitrogen) containing $20 \mathrm{~mm}$ glucose. Meninges were stripped, and cords were minced and placed into an $\mathrm{O}_{2}$ saturated papain solution (Worthington Biochemicals) for $20 \mathrm{~min}$. The tissue was washed twice with spinal cord astrocyte media (EMEM supplemented with $10 \%$ fetal calf serum, $20 \mathrm{~mm}$ glucose, and penicillin/streptomycin) and then triturated. A high density of cells $\left(1.0 \times 10^{6}\right.$ cells $\left./ \mathrm{ml}\right)$ was plated in a small volume $(50 \mu \mathrm{l})$ onto polyornithine- and laminin-coated 0.170 mm-thick glass-bottom $35 \mathrm{~mm}$ dishes (Mattek). This allowed cells to adhere to the glass. After $4 \mathrm{~h}$, an additional $2 \mathrm{ml}$ of media was added to each well. Cultures were maintained at $37^{\circ} \mathrm{C}, 5 \% \mathrm{CO}_{2}$, and the media were changed every day for the first $3 \mathrm{~d}$ and then every fourth day thereafter.

Three-dimensional time-lapse volume determination. Threedimensional (3D) confocal images were acquired with a Hamamatsu IEEE1394 Digital CCD camera mounted on an Olympus IX81 motorized inverted microscope equipped with an Olympus Disk Scanning Unit (DSU) and controlled by Slidebook software (Intelligent Imaging Innovations). The microscope was housed in a temperature- and $\mathrm{CO}_{2}^{-}$ controlled humidified incubator maintained at $37^{\circ} \mathrm{C}$ and $5 \% \mathrm{CO}_{2}$ for $3 \mathrm{D}$ time-lapse experiments. Image stacks were acquired with $0.5 \mu \mathrm{m}$ steps throughout the depth of the cells for both GFP (excitation, $482 \pm 17 \mathrm{~nm}$; emission, $536 \pm 20 \mathrm{~nm}$ ) and Hoechst (excitation, $387 \pm 11 \mathrm{~nm}$; emission, $447 \pm 30 \mathrm{~nm}$ ). Stacks were acquired at $30 \mathrm{~min}$ intervals through a $40 \times$ oil objective (numerical aperture, 1.3), and the camera was binned to minimized light exposure and phototoxicity. Image stacks were converted to a series of 16-bit TIF files and imported into Image Pro 3D Suite (Media Cybernetics) in which image volume measurements were made based on pixel intensity in the $x-y$ plane throughout the $z$ depth of the stack.

$2 D$ time-lapse imaging. Glioma cells were grown in \#1 German borosilicate two- or four-well chamber slides (Nalge Nunc International). All imaging experiments were performed $24-48 \mathrm{~h}$ after plating for glioma cells and 3-5 d after dissection for astrocytes. When nuclear condensation was accessed, Hoechst 33342 was loaded into cells at a concentration of $100 \mathrm{ng} / \mathrm{ml}$ in normal culture media for $25 \mathrm{~min}$. After washing, cells were allowed $1-2 \mathrm{~h}$ to recover before imaging. For experiments in which U251-MG cells and astrocytes were loaded with CellTracker Green CMFDA (5-chloromethylfluorescein diacetate) (Invitrogen), a $10 \mu \mathrm{M} \mathrm{solu-}$ tion of the dye was made up in loading media composed of serum/ glutamine free media 1:1 DMEM/F-12 warmed to $37^{\circ} \mathrm{C}$. Cells were washed three times in loading media without CMFDA to remove serum and glutamine and then covered with the $10 \mu \mathrm{M}$ CMFDA solution. After $45 \mathrm{~min}$ incubation at $37^{\circ} \mathrm{C}$, the dye solution was removed, and cells were washed once with loading media and three times with normal culture media. Imaging experiments were conducted $12-24 \mathrm{~h}$ after loading to allow for recovery.

Time-lapse images were acquired with an Axiocam MRm camera mounted on an Axiovert 200M inverted microscope with a motorized stage and filter cube turret (Carl Zeiss). The microscope was housed in a temperature- and $\mathrm{CO}_{2}$-controlled humidified incubator maintained at $37^{\circ} \mathrm{C}$ and $5 \% \mathrm{CO}_{2}$, and cells were imaged in their respective normal culture media. Wide-field fluorescence was generated from a metal halide X-cite 120 light source (EXFO Photonics Solutions) and reflected through an FITC (excitation, $480 \pm 15 \mathrm{~nm}$; emission, $535 \pm 20 \mathrm{~nm}$ ) filter cube for GFP or CMFDA fluorescence or a $4^{\prime}, 6^{\prime}$-diamidino-2phenylindole (DAPI) (excitation, $350 \pm 25 \mathrm{~nm}$; emission, $460 \pm 25 \mathrm{~nm}$ ) filter cube (Chroma Technologies) for Hoechst 33342 fluorescence. Neutral density filters were used to attenuate light and prevent phototoxity. 2D time-lapse experiments were conducted with a $20 \times$ Fluar air objective. Images were acquired at 5-20 min intervals depending on cell type and duration of experiment. Intensity measurements for GFP and Hoechst 33342 were made from 16-bit TIF files in NIH Image J within regions of interest (ROIs) selected to reflect the mean cytoplasmic or nuclear intensity, respectively. Measurements were reflective of mean pixel intensity within that ROI and, therefore, not dependent on ROI size from image to image. Values were normalized by creating a ratio of the intensity at a given time to the intensity at the last imaged time point before division $(t=0)$.

Immunocytochemistry. D54-MG cells were plated on uncoated $12 \mathrm{~mm}$ round \#1 glass coverslips (Macalaster Bicknell) in 24-well plates at a density of $\sim 10,000$ cells per well. After $72 \mathrm{~h}$ in culture, cells were fixed for 10 min at room temperature $\left(25^{\circ} \mathrm{C}\right)$ with $4 \%$ paraformaldehyde in PBS, washed three times with $\mathrm{PBS}$, and then permeabilized with $0.3 \%$ Triton $\mathrm{X}-100$ in PBS plus 5\% normal goat serum (NGS). After the detergent was removed and the coverslips were washed, cells were covered with 5\% NGS in PBS for $1 \mathrm{~h}$ at room temperature or overnight at $4^{\circ} \mathrm{C}$. Primary antibodies were diluted in PBS containing 1\% NGS and incubated for 2-3 h at room temperature, followed by three washes with PBS and a 30 min incubation with 5\% NGS PBS to block nonspecific binding of the secondary antibodies. Secondary antibodies were diluted in 1\% NGS PBS and incubated $1 \mathrm{~h}$ at room temperature, followed by three PBS washes. Before mounting, cells were loaded with Hoechst 33342 at $100 \mathrm{ng} / \mathrm{ml}$ in PBS for $20 \mathrm{~min}$. Coverslips were mounted onto 3 inch $\times 1$ inch $\times 1 \mathrm{~mm}$ slides (Fischer Scientific) with Gel-Mount aqueous mounting media (Sigma).

$\mathrm{ClC} 3$ was immunolabeled with either a commercially available rabbit polyclonal anti-ClC3 antibody to the $\mathrm{C}$ terminus of $\mathrm{ClC} 3$ at a final concentration of $1.5 \mu \mathrm{g} / \mathrm{ml}$ (Alomone Labs) or a polyclonal rabbit antibody to the $\mathrm{C}$ terminus referred to as $15 \mathrm{~K}$ and kindly provided by Dr. William J. Hatton (University of Nevada School of Medicine, Reno, NV). Final working concentration of the $15 \mathrm{~K}$ antibody was $2.7 \mu \mathrm{g} / \mathrm{ml}$. A FITClabeled monoclonal mouse antibody to $\alpha$-tubulin (ab11303) was purchased from Abcam and diluted as suggested by the manufacturer. Alexa Fluor 488- and 546-labeled goat anti-mouse and goat anti-rabbit secondary antibodies were purchased from Invitrogen. Semiconfocal fluorescent images were acquired with a $60 \times$ oil immersion lens (numerical aperture, 1.42) on the Olympus IX81 motorized inverted microscope described above. Alexa 546 was imaged with a tetramethylrhodamine isothiocyanate filter set (excitation, $543 \pm 22 \mathrm{~nm}$; emission, $593 \pm 20$ $\mathrm{nm}$ ), Alexa 488 was imaged with an FITC set (excitation, $482 \pm 17 \mathrm{~nm}$; emission, $536 \pm 20 \mathrm{~nm}$ ), and Hoechst 33342 was imaged with a DAPI filter set (excitation, $387 \pm 5.5 \mathrm{~nm}$; emission, $447 \pm 30 \mathrm{~nm}$ ) (Semrock). Out-of-focus light was removed by the DSU.

shRNA and control stable cell lines. To knockdown ClC3 expression in the D54-MG cell line, we obtained commercially available pGIPZlentiviral shRNAmir vectors containing either a nonsilencing scrambled sequence that does not match any known mammalian genes (NS) or one 
of three hairpin sequences targeting CLCN3 (Open Biosystems). The hairpin sequences were as follows, with underlined sequencing corresponding to region of the human CLC3 gene targeted: F3, 5'TGCTGTTGACAGTGAGCGCG GTGTT GGTACATATGATGATTAGTGAAGCCA CAGATGTAATCATCATATG TACCAACACCTTGCCTACTGCCTCGGA-3'; A4， 5'-TGCTGTTGACAGTGAGCG CGCCTGG AAGAGGTTAGCTATTTAGTG AAGCCACAGATGTAAATAGCTAACCTCTTCCAGGCTTGCCTACTGCCT CGGA3'; H8, 5'-TGCTGTTGACAGTGAG CGCCCTACCTCTTTCCAA AGTATAT AGTGAAGCCACAGATGTATATA CTTTGGAAAGAGGTAGGATGCC TACTGCCTCGGA-3'; NS, 5' '-TGCTGTTGACAGTGAGCGATCTCGCTTGG GCGA GAG TAAGTAGTGAAGCC ACAGATGTACTTACTCTCGCCCAAGCGA GAGTG CCTA CTGCCTCGGA$3^{\prime}$. D54-MG cells were transfected with the Amaxa Biosystems nucleofection technique as directed by the manufacturer. Briefly, cells were grown to $\sim 80 \%$ confluency in $10 \mathrm{~cm}$ dishes, trypsinized, pelleted, and resuspended in supplemented Nucleofector Solution for a final cell density of $0.5-1.5$ million cells per $100 \mu \mathrm{l}$ of solution. The cell solution was then mixed with $1 \mu \mathrm{g}$ of plasmid DNA/100 $\mu \mathrm{l}$, transferred to an electroporation cuvette, and subjected to an electroporation protocol optimized for the D54-MG line. Transfected cells were transferred to $60 \mathrm{~mm}$ dishes containing prewarmed media and incubated under normal culture conditions. Media was changed $24 \mathrm{~h}$ after transfection to remove cells that did not survive electroporation. To generate the stable lines, $10 \mu \mathrm{g} / \mathrm{ml}$ puromycin treatment was begun $96 \mathrm{~h}$ after transfection. Media was changed regularly to remove cellular debris and dead cells throughout the selection period until colony formation was visibly evident $(\sim 2-3$ weeks) and all cells expressed the vector encoded GFP. For the A4 cell line, all colonies were combined and amplified in the presence of puromycin. For the H8 and F3 lines, individual colonies were transferred to separate dishes with a pipette tip and amplified in the continued presence of puromycin under otherwise normal culture conditions.

Immunoprecipitation. Whole-cell lysates were diluted to equal concentrations $(1 \mathrm{mg} / \mathrm{ml})$. These samples were precleared, with $75 \mu \mathrm{l}$ of protein A beads (Roche Applied Science) if the precipitating antibody was generated in rabbit or protein $\mathrm{G}$ beads (Roche Applied Science) if the precipitating antibody was generated in mouse, for $1 \mathrm{~h}$. Agarose beads were equilibrated by washing and pelleting the beads on low speed three times in RIPA buffer [50 mM Tris-Cl, $\mathrm{pH} 7.5,150 \mathrm{~mm} \mathrm{NaCl}$, and $1 \%$ Nonidet P-40 (NP-40)]. Antibodies were added to the pre-cleared lysates at 2-3 $\mu \mathrm{g} / \mathrm{ml}$ and incubated overnight at $4^{\circ} \mathrm{C}$. The next day, $60 \mu \mathrm{l}$ of the appropriate agarose beads was added to each sample for an additional $2-4 \mathrm{~h}$ at $4^{\circ} \mathrm{C}$. Immunoprecipitates were pelleted at low speed and washed four times in RIPA buffer. To release the immunoprecipitates from the beads, $2 \mathrm{X}$ sample buffer $(50 \mu \mathrm{l})$ was added and samples were boiled for $5 \mathrm{~min}$. Blots were run as described below. Mouse and rabbit tubulin antibodies were obtained from Abcam and used according to manufacturer's suggestions.

Western blot protocol. Cultured cells were lysed using RIPA buffer (50

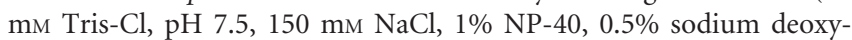
cholate, and $1 \%$ SDS) for $30 \mathrm{~min}$ supplemented with a protease and phosphatase inhibitor cocktail obtained from Sigma. Lysates were sonicated for $10 \mathrm{~s}$, and the homogenates were centrifuged for $5 \mathrm{~min}$ at $12,000 \times g$ at $4^{\circ} \mathrm{C}$. Protein quantification was performed on the supernatant using a DC protein assay kit from Bio-Rad. Protein was heated to $60^{\circ} \mathrm{C}$ in $2 \times$ buffer $(100 \mathrm{~mm}$ Tris, $\mathrm{pH} 6.8,4 \%$ SDS, $0.2 \%$ bromophenol blue, 20\% glycerol, and $200 \mathrm{~mm}$ dithithreitol) for $15 \mathrm{~min}$. Equal amounts of protein were loaded into each lane of a $7.5 \%$ gradient precast SDS gel (Bio-Rad). Proteins were separated at 120 V constant. Gels were transferred onto polyvinylidene difluoride paper (Millipore) at $200 \mathrm{~mA}$ constant for $2 \mathrm{~h}$ at room temperature, and these membranes were blocked in blocking buffer [10\% milk in TBST (Tris-buffered saline and Tween 20)] for $1 \mathrm{~h}$ by room temperature. Two $\mathrm{ClC} 3$ antibodies were used to probe the blots: ClC3 (Alomone Labs) and 14K (kindly provided by Dr. William J. Hatton). The membranes were incubated in primary antibody overnight at $4^{\circ} \mathrm{C}$. The following day, the membranes were washed three times for $15 \mathrm{~min}$ in TBST and then incubated with horseradish peroxidase-conjugated secondary antibody for $60 \mathrm{~min}$ at room temperature. Blots were again washed three times for $10 \mathrm{~min}$ and developed with
Super Signal West Fempto enhanced chemiluminescence (Thermo Fisher Scientific) using an Eastman Kodak Image Station 4000 MM. Secondary horseradish peroxidase-conjugated antibodies were purchased from Santa Cruz Biotechnology). ClC3 immunoreactivity was normalized to actin (Sigma), the $\mathrm{Na}^{+} / \mathrm{K}^{+}$ATPase (Millipore Bioscience Research Reagents), or glyceraldehyde-3-phosphate dehydrogenase (Abcam).

Electrophysiology. Whole-cell patch-clamp recordings were acquired from glioma cells $72 \mathrm{~h}$ after plating using standard whole-cell patchclamp techniques (Hamill et al., 1981). Patch pipettes were pulled from thin-walled borosilicate glass (TW150F-4; World Precision Instruments) with an upright puller (PP-830; Narishige) to a resistance of 3-5 M $\Omega$. An Axopatch 200A amplifier (Molecular Devices) was used, and currents were low-pass filtered at $1 \mathrm{kHz}$ and then digitalized on-line at $10 \mathrm{kHz}$ using a Digidata 1322A (Molecular Devices). Data was acquired and stored with the use of pClamp 8 (Molecular Devices). Whole-cell capacitance and series resistance was measured from the amplifier, and compensation was adjusted to $80 \%$. Standard pipette $\mathrm{KCl}$ pipette solution contained the following (in $\mathrm{mm}$ ): $140 \mathrm{KCl}, 1 \mathrm{MgCl}_{2}, 10 \mathrm{EGTA}$, and 10 HEPES sodium salt, $\mathrm{pH}$ adjusted to 7.2 with Tris base. Osmolarity was adjusted to $302 \mathrm{mOsm}$. Normal extracellular $\mathrm{NaCl}$ bath solution contained the following (in $\mathrm{mM}$ ): $130 \mathrm{NaCl}, 5 \mathrm{KCl}, 1 \mathrm{CaCl}_{2}, 10.5$ glucose, and 32.5 HEPES acid. $\mathrm{pH}$ was adjusted to 7.4 , and osmolarity ranged from 306 to $312 \mathrm{mOsm} / \mathrm{kg}$.

Statistical analysis. Current subtractions and current-voltage relationships from electrophysiological recordings were determined using Clampfit (Molecular Devices). For all experiments, raw data were analyzed and plotted using Origin 6.0 software (Microcal Software). Appropriate statistical tests were chosen according to the type of data analyzed and performed using GraphPad Instat (GraphPad Software). Unless otherwise stated, all measurements are reported with SE, and $n$ refers to the number of cells analyzed.

\section{Results \\ Cytoplasmic condensation is a normal part of mitosis in immature and transformed glial cells}

We previously described a novel phenomenon in glioma cells, namely a cytoplasmic volume condensation just before cell division, which we termed PMC. Notably, this process is functionally linked to the condensation of chromatin as cells of the D54-MG glioma line approach cell division (Habela and Sontheimer, 2007). To examine the relevance of PMC to glioma and glial cell biology in general and investigate the mechanism behind this process, we used fluorescent time-lapse microscopy to measure volumetric changes in live, spontaneously dividing, and adherent cells throughout the cell cycle. These experiments are based on the concept that changes in cytoplasmic volume can be measured by changes in the fluorescence intensity of freely diffusible dyes or fluorescent proteins as fluorescence varies inversely in proportion to the concentration of the fluorescent molecule. This relationship between volume and fluorescence intensity is illustrated in Figure 1 in which D54-GFP cells were imaged in $0.5 \mu \mathrm{m}$ optical sections throughout their depth to generate threedimensional objects in a time-lapse series (Fig. 1A, left). Relative volumetric information extracted from a single cell in these $3 \mathrm{D}$ images is plotted against time normalized to the last time point before division in Figure $1 B$ (open circles). Shown on the same graph (filled squares) is the relative intensity of the GFP fluorescence within a single place of the same stack (Fig. $1 A$, right panels). As the volume decreases over a relatively short period of time, the intensity of the GFP is increased as a result of the concentration of the molecule. Changes in fluorescence intensity, therefore, can be used as a surrogate for volumetric measurements when 3D measurements are impractical because of required time resolution and number of fields to be analyzed.

Using such 2D time-lapse techniques, we confirmed that, as 
D54-MG glioma cells stably expressing GFP freely proliferate under normal culture conditions, the entrance into mitosis and approach to metaphase is accompanied by an increase in the fluorescence intensity ratio $\left(F / F_{m}\right)$ such that the peak $F / F_{m}$ value is reached at the last time point before anaphase $(t=0)$ (Fig. $1 C$, filled squares). Although GFP intensity can be affected by changes in $\mathrm{pH}$, we determined using the ratiometric $\mathrm{pH}$ indicator $\mathrm{BCECF}$ [2',7' -bis-(2-carboxyethyl)-5-(and-6)carboxyfluorescein] that no significant intracellular $\mathrm{pH}$ changes occurred during the analysis period (data not shown) and fluorescence intensity changes were truly representative of a significant change in cell volume. These data, therefore, indicate that a large and rapid change in cytoplasmic volume occurs as D54-MG cells progress to division. This process precedes and is closely associated with the process of DNA condensation that occurs between prophase and metaphase of mitosis and can be measured by the relative increase in the intensity of the nucleic acid binding dye Hoechst 33342, which is concentrated as the DNA condenses (Fig. $1 A$, right, $C$, open circles). This phenomenon of PMC coupled to DNA condensation is a novel observation that opposes the commonly held belief that cells achieve their largest volume just before division (Jorgensen and Tyers, 2004). This concept is important because it accentuates structural and physical changes as factors that may be equally as important as growth factor signaling and phosphorylation cascades to regulating the proliferative capacity of these cells.

Importantly, this phenomenon is not specific to cells of the D54 cell line, because it was also observed when we analyzed mitotic events in a different glioma cell line (U251-MG) (Fig. $1 D$ ) or in immature cultured spinal cord astrocytes (Fig. $1 E$ ). The example experiment in Figure $1 D$ demonstrates that U251-MG cells loaded with the fluorescent cytoplasmic dye CMFDA (filled symbols) undergo a similar volume decrease within the hour preceding division as occurs in GFPexpressing D54-MG cells. Likewise, when spinal cord astrocytes loaded with CMFDA were examined by 2D time-lapse microscopy at $3-5 \mathrm{~d}$ in culture, PMC was also observed (Fig. $1 E$, filled symbols). Primary rodent astrocytes were used as a model for nonmalignant glial cells because they have been studied extensively in the glial literature and show a high rate of proliferation immediately after plating. By comparison, human astrocytes cultured from adult biopsy tissues rarely divide, making such studies technically challenging. However, the observation that PMC occurs similarly in gliomas and nonmalignant rodent astrocytes suggests that this process is likely to resemble an integral part of cell proliferation in neural cells, although this phenomenon warrants additional examination in human astrocytes in the future

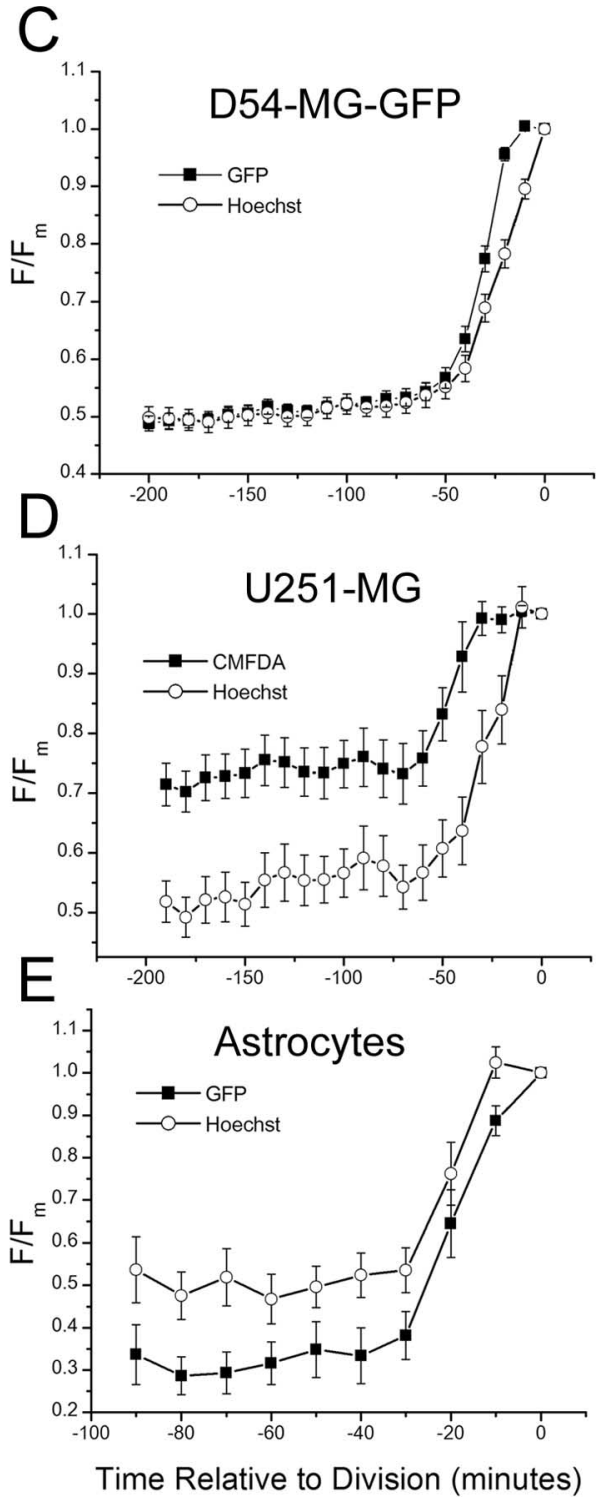

Figure 1. Premitotic condensation occurs in glioma cells and spinal cord astrocytes. $\boldsymbol{A}$, Example glioma cell approaching division from top to bottom demonstrated in 3D (left) and 2D (right two columns). Scale bar, $10 \mu \mathrm{m}$. $\boldsymbol{B}$, Relationship between volume (open circles) and intensity measurements (filled squares) for cell in $\boldsymbol{A}$. $\boldsymbol{C}-\boldsymbol{E}, 2 \mathrm{D}$ time-lapse curves with cytoplasmic repeated five times. $\boldsymbol{D}$, Example 2D time-lapse experiment for dye-loaded U251-MG cells. $n=9$. Similar results observed in four independent experiments. $\boldsymbol{E}$, Example 2D time-lapse experiment for dye-loaded cultured rat spinal cord astrocytes. $n=9$ dividing cells. Similar results observed in three independent experiments.

The PMC seen in D54-MG and U251-MG cells, as well as in cultured astrocytes, was temporally linked to DNA condensation (Fig. 1C-E, open symbols). These data imply that PMC is a normal part of cell division in normal and malignant cells in the brain. Because we previously established in D54 cells (Habela and Sontheimer, 2007) that the rate of this process plays a role in determining the rate of DNA condensation and therefore progression through mitosis, the observation that this process occurs in multiple cell types is important. Cellular characteristics that determine proliferative capacity are important to normal brain development and maintenance in addition to disease processes. We, therefore, sought to investigate the mechanism by which such a significant change in volume is coupled to the nuclear changes that occur during mitosis. The condensation of the cy- 
A

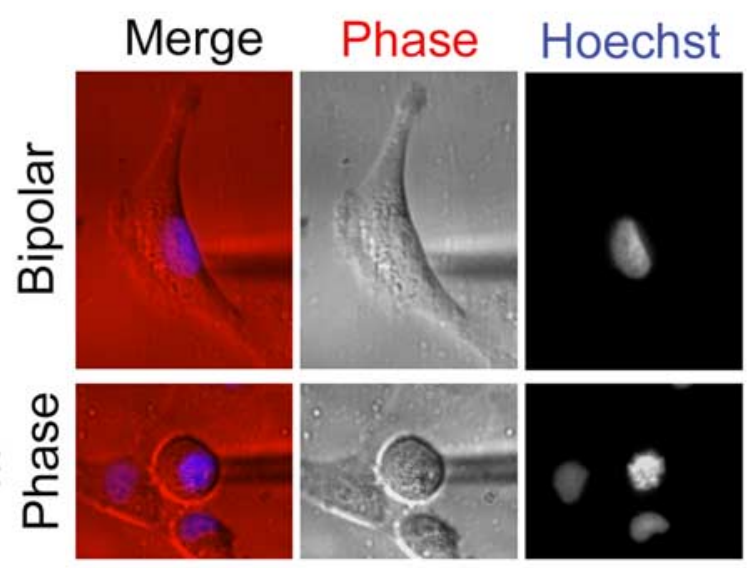

B
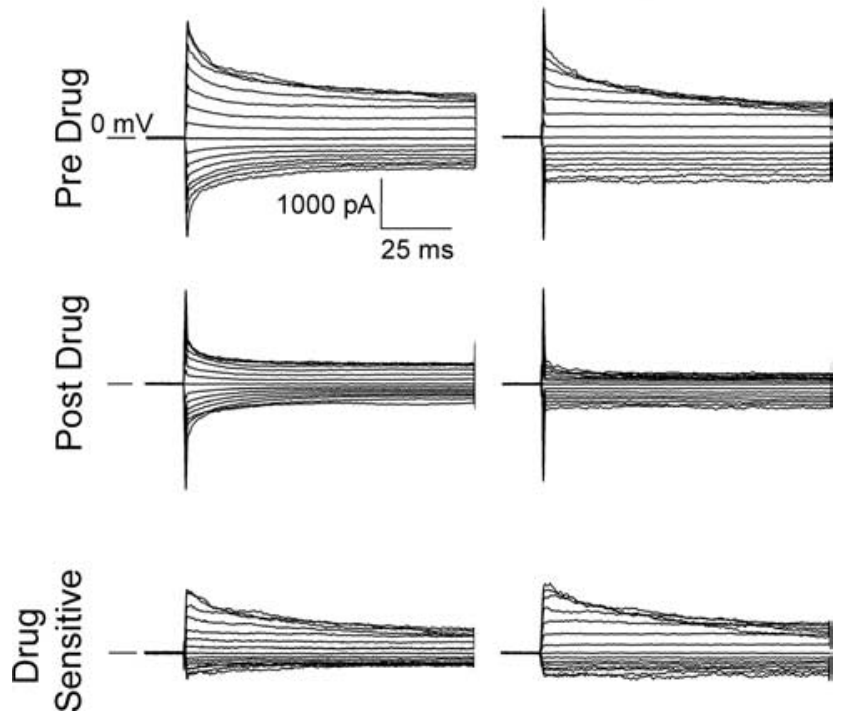

Figure 2. Mitotic cells have increased chloride current densities. $\boldsymbol{A}$, Example cells for bipolar (top) and $M$ phase (bottom). Mitotic cells have distinct cell body morphology (phase), and DNA condensation is evident (Hoechst). Magnification, $40 \times$. B, Example current traces from recordings of $\mathrm{M}$ phase cells before (top) and after (middle) chloride channel inhibitors. Bottom traces are drug-sensitive currents. All traces are to scale at top left.

toplasmic volume requires the coordinated efflux of cytoplasmic water driven by $\mathrm{K}^{+}$and $\mathrm{Cl}^{-}$. In most cell types, volume reduction is intrinsically associated with the activation of chloride channels.

\section{PMC is associated with an outwardly rectifying chloride current}

The process of PMC was shown to be associated with an increase in the magnitude of an outwardly rectifying, time-dependentinactivating, NPPB-sensitive current that reversed at $0 \mathrm{mV}$ (Habela and Sontheimer, 2007). This suggested the involvement of a chloride current and prompted us to further study the electrophysiological profile of mitotic cells in the process of condensation. M phase and growth phase cells were distinguished based on cell body morphology and Hoechst labeling to determine chromatin condensation for whole-cell patch-clamp recordings (Fig. $2 A)$. Entrance potential measurements indicated a mean resting membrane potential (RMP) of $-26.1 \pm 1.1 \mathrm{mV}(n=58)$ for $\mathrm{M}$ phase cells and $-32.5 \pm 1.8 \mathrm{mV}(n=40)$ for the bipolar growth phase cells. $M$ phase cells were significantly more depolarized than the bipolar cells ( $p=0.001$, two-tailed $t$ test). Additionally, the measured whole-cell capacitance for M phase cells was $40.1 \pm$ $0.93 \mathrm{pF}(n=58)$ and for bipolar cells was $55.6 \pm 2.4 \mathrm{pF}(n=40)$ $(p<0.0001$, two-tailed $t$ test). This decrease in capacitance in the mitotic cells is indicative of a decreased membrane surface area and is consistent with the observed decrease in cell volume in these cells.

To examine membrane chloride current profiles, voltage steps were applied for $100 \mathrm{~ms}$ from -140 to $+140 \mathrm{mV}$ at $20 \mathrm{mV}$ intervals to cells with discernable chromatin condensation in prometaphase or metaphase (Fig. $2 A$, bottom). The resulting currents were compared with those elicited from large bipolar cells with round uncondensed nuclei (Fig. $2 A$, top). In the presence of $2 \mu \mathrm{M}$ paxilline $(\mathrm{Pax})$ to inhibit the major $\mathrm{K}^{+}$conductance in these cells (Ransom and Sontheimer, 2001), we were able to isolate the majority of the remaining current with either of the nonspecific chloride channel inhibitors DIDS and NPPB. As shown by the example currents from M phase cells in Figure 2 B, $200 \mu \mathrm{M}$ DIDS inhibited a qualitatively similar current to that inhibited by $200 \mu \mathrm{M} \mathrm{NPPB}$, and both the NPPB- and the DIDS-sensitive currents were significantly larger in $\mathrm{M}$ phase cells compared with bipolar cells. There was an approximate twofold increase in the NPPB-sensitive current for the $\mathrm{M}$ phase cells compared with the bipolar cells (M phase, $14.6 \pm 2.289 \mathrm{pA} / \mathrm{pF}, n=35$ vs bipolar, $9.195 \pm 1.706 \mathrm{pA} / \mathrm{pF}, n=27$; one-tailed $t$ test, $p<0.05)$ and a threefold increase in the DIDS-sensitive current density in $\mathrm{M}$ phase cells (M phase, $6.5 \pm 1.4 \mathrm{pA} / \mathrm{pF}, n=23$ vs bipolar, $2.2 \pm 0.9$ $\mathrm{pA} / \mathrm{pF}, n=13$; one-tailed $t$ test, $p<0.05)$. Consistent with the current being carried by chloride, it was unaltered if extracellular $\mathrm{Cl}^{-}$was replaced by $\mathrm{Br}^{-}$, which is known to permeate most chloride channels (data not shown). This substitution brought about a significant $-3.05 \pm 0.87 \mathrm{mV}$ shift in the reversal potential of the whole-cell Pax-insensitive currents ( $n=10$; onepopulation $t$ test, $p<0.01$ ), indicating that permeability to $\mathrm{Br}^{-}$is slightly greater than to $\mathrm{Cl}^{-}$with a $P_{\mathrm{Br}^{-}} / P_{\mathrm{Cl}^{-}}$ratio of 1.1 calculated from the constant field potential equation as described by Olsen et al. (2003). The biophysical characteristics of an outwardly rectifying, time- and positive voltage-dependent inactivating $\mathrm{Cl}^{-}$ current that is sensitive to both NPPB and DIDS is consistent with either $I_{\mathrm{ClC} 3}$ or $I_{\mathrm{Cl}-\text { Swell }}$ (Duan et al., 1997; von Weikersthal et al., 1999; Jin et al., 2003; Olsen et al., 2003). These currents and the means to definitively distinguish between the two, however, have been a source of controversy.

ClC3 localization is altered in a cell-cycle-dependent manner There are no specific inhibitors for either of these currents, and the molecular identity of the channel that conducts $I_{\mathrm{Cl}-\text { Swell }}$ is to date unknown. However, a long and a short form of the voltagedependent $\mathrm{Cl}^{-}$channel family member $\mathrm{ClC} 3$ have been cloned (Kawasaki et al., 1994; Borsani et al., 1995; Shimada et al., 2000; Huang et al., 2001) and characterized in knock-out animals (Stobrawa et al., 2001; Dickerson et al., 2002; Yoshikawa et al., 2002; Yamamoto-Mizuma et al., 2004) and by transient knockdown with antisense oligonucleotides and shRNA (L. Wang et al., 2000; G. L. Wang et al., 2002; Olsen et al., 2003; Mao et al., 2008). Furthermore, this channel has been shown previously to be present in multiple glioma cell lines by reverse transcription-PCR and Western blot analysis (Olsen et al., 2003; Ernest et al., 2005). Its presence and activity on the cell surface of D54-MG cells has been determined using electrophysiology in combination with oligonucleotide antisense and by electron microscopy (Olsen et al., 2003), and its involvement in processes of physiological vol- 

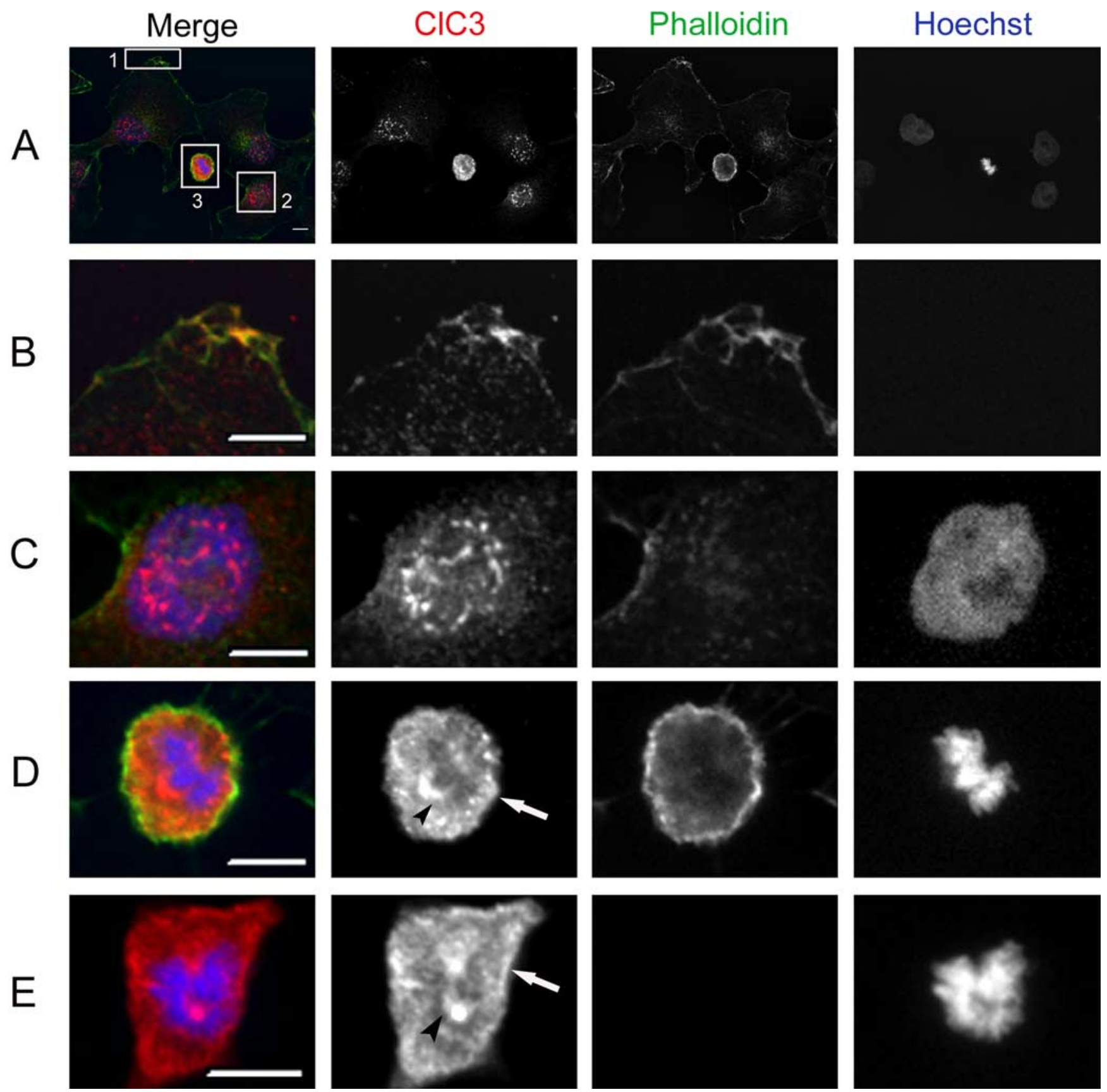

Figure 3. CIC3 is present on the plasma membrane and associates with DNA. $A$, Immunofluorescence images of fixed D54-MG cells stained with an antibody to CIC3 (15K), FITC-conjugated phalloidin, and Hoechst 33342 . This field contains both growth phase cells and a cell undergoing mitosis. Boxes $1-3$ correspond to images in $\boldsymbol{B}-\boldsymbol{D}$. B, CIC3 colocalizes with the subcortical actin. $\boldsymbol{C}$, CIC3 localizes to the nucleus in growth phase cells. D, E, Examples of CIC3 localization in two different M phase cells. Arrows indicate the plasma membrane. Arrowheads indicate spindle structures delineated by CIC3. Scale bars, $10 \mu \mathrm{m}$. Images are representative of five independent experiments using two different antibodies to CIC3.

ume regulation and cell cycle progression in other cell types (von Weikersthal et al., 1999; L. Wang et al., 2000; G. L. Wang et al., 2002; Duan et al., 2001; Jin et al., 2003) makes it a good candidate for the molecular entity in this process.

If $\mathrm{ClC} 3$ is the channel responsible for the currents observed in mitotic cells, then one possible explanation for the increase in magnitude would be that there is differential membrane localization of the channel in mitotic cells compared with normal growth phase cells. We examined this using confocal immunofluorescence microscopy. D54-MG cells were paraformaldehyde fixed $72 \mathrm{~h}$ after plating and fluorescently stained with either a polyclonal rabbit antibody to the $\mathrm{C}$ terminus of $\mathrm{ClC} 3$ alone or in combination with FITC-labeled phalloidin staining. Figure $3 \mathrm{~A}$ shows a confocal section taken of an example field that contains large growth phase cells and a mitotic cell at metaphase, demonstrated by Hoechst labeling (blue). In growth phase cells, consistent with work by others (Zhao et al., 2007), ClC3 (red) appeared to be colocalized with the cortical actin skeleton at the cell membrane (Fig. $3 A$, box $1, B$ ) in addition to localizing to punctuate endosomal-like structures in the cytoplasm (Fig. $3 B, C$ ). Interestingly, there was also strong $\mathrm{ClC} 3$ labeling in the nucleus associated with the Hoechst-labeled DNA (Fig. 3A, box 2, C).

In the mitotic cells, as demonstrated by Figure $3, D$ and $E$, $\mathrm{ClC} 3$ immunofluorescence throughout the cell was significantly 


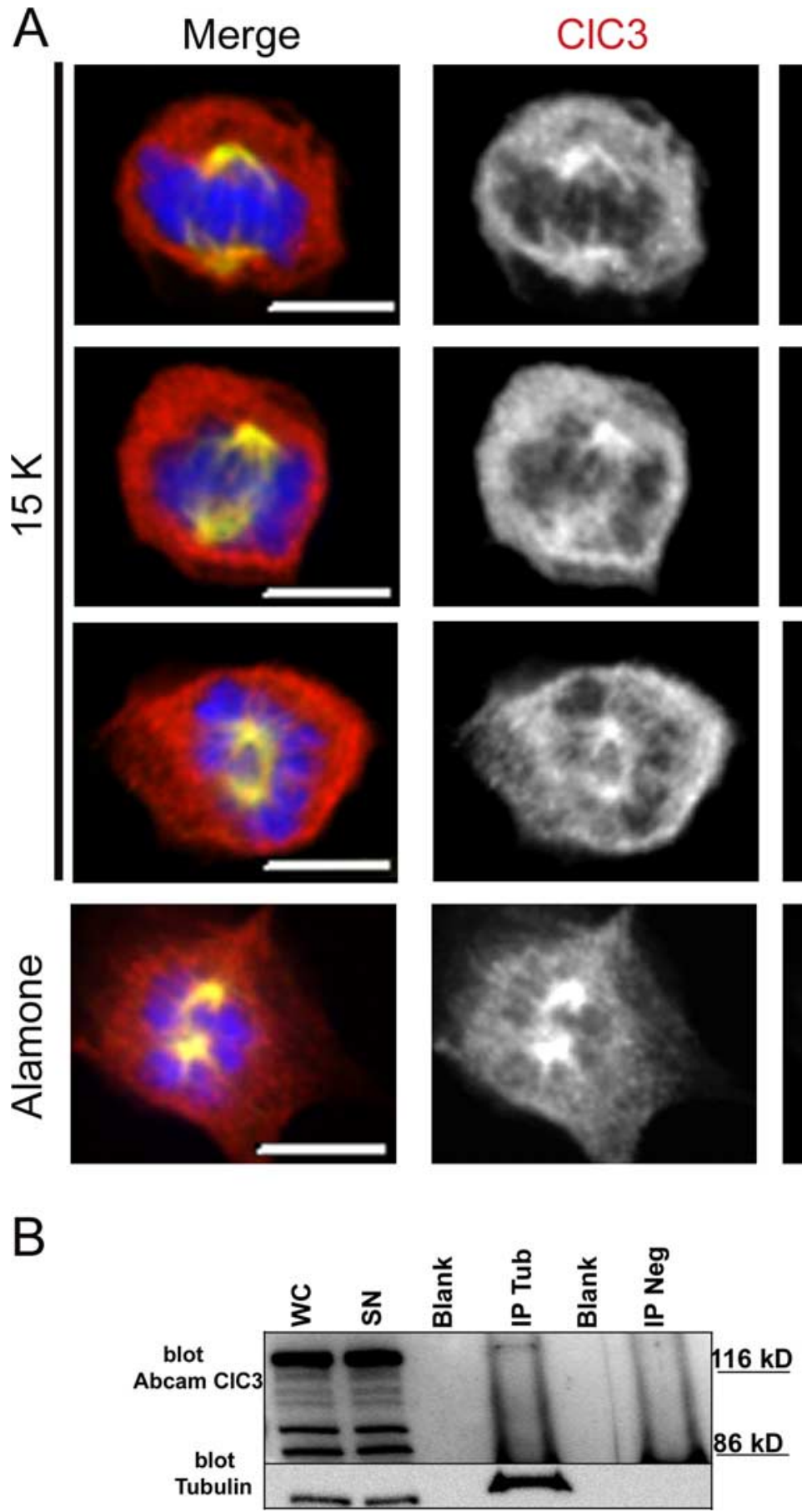

Figure 4. CIC3 colocalizes with $\alpha$-tubulin at the mitotic spindle. $\boldsymbol{A}$, Immunofluorescent images of four different cells in various stages of mitosis. Cells are labeled with either $15 \mathrm{~K}$ anti-CIC3 or Alomone Labs anti-CIC3 antibodies (red) and FITC-labeled anti- $\alpha$-tubulin (green). DNA is stained with Hoechst 33342 (blue). Colocalization is indicated by yellow in merged panels. Scale bar, $10 \mu \mathrm{m}$. Images are representative of five independent experiments. $\boldsymbol{B}$, Representative Western blot of a mouse anti- $\alpha$-tubulin immunoprecipitation probed with Abcam anti-CIC3 antibody (top) and rabbit anti- $\alpha$-tubulin (bottom). WC, Whole-cell lysates; $S N$, supernatant; IP Tub, $\alpha$-tubulin immunoprecipitation; IP Neg, no antibody control. Similar results observed in three independent experiments.

more intense, as would be expected for a cell in which the cytoplasmic volume has been condensed. However, the brightest staining was in the region of the cortical actin (arrows) as well as associated with the condensed chromosomes. This suggests that, in the condensing (Fig. 3E) and fully condensed (Fig. 3D) mitotic cells, ClC3 is preferentially localized to the membrane, which may account for an increase in the amplitude of membrane currents. Additionally, the $\mathrm{ClC} 3$ localization was reminiscent of the spindle formation (Fig. $3 D, E$, arrowheads). In an attempt to put this staining into context, we counterstained D54-MG cells with an FITC-labeled monoclonal antibody to $\alpha$-tubulin. Figure $4 A$ demonstrates single plane confocal images of $\mathrm{ClC} 3$ localization in four separate mitotic cells that were stained with two antibodies recognizing two separate epitopes in the $\mathrm{C}$ terminus of the $\mathrm{ClC} 3$ protein (Alomone Labs and 15K). Interestingly, the spindle morphology illustrated by the $\alpha$-tubulin labeling was mimicked by the discrete DNA-associated staining from both antibodies in the ClC3 panels. This colocalization is most evident in the merged panels in which $\mathrm{ClC} 3$ is depicted in red, $\alpha$-tubulin is depicted in 
green, and pixels in which the fluorescence overlaps appear yellow.

To determine whether this spindle-associated staining was in fact attributable to an interaction between $\mathrm{ClC} 3$ and tubulin, we immunoprecipitated $\alpha$-tubulin with a monoclonal antibody and protein $\mathrm{G}$ agarose beads. Whole-cell lysates as well as precipitates were subjected to SDS-PAGE and Western blot analysis with polyclonal rabbit antibodies against $\mathrm{ClC} 3$. As shown in an example blot in Figure $4 B$, ClC3 antibodies recognize an $\sim 120 \mathrm{kDa}$ band in the immunoprecipitate but not in the negative control. This is similar to the molecular weight that has been published for glycosylated $\mathrm{ClC} 3$ and indicates that it physically interacts with tubulin. This implies that, in addition to being a candidate for the channel responsible for mitotic chloride currents, $\mathrm{ClC} 3$ may play a more direct role in the structural changes that occur in the DNA as mitosis progresses.

\section{M phase chloride currents are diminished by ClC3 knockdown}

Decreased proliferation rates have been reported for multiple normal and cancerous cell types in the presence of NPPB and/or DIDS (Shen et al., 2000; Wondergem et al., 2001; Chen et al., 2002; Zheng et al., 2003), supporting a possible role for membrane expressed CLC3 in the progression of the cell cycle, yet the promiscuity of chloride channel inhibitors makes linking pharmacology to molecular entities very difficult. We therefore used shRNA constructs to determine the role of $\mathrm{ClC} 3$ in PMC. D54-MG cells were transfected with three pGIPZ-shRNAmir vectors containing short hairpin sequences that target three unique sites of the human $\mathrm{ClC} 3$ gene and that are included in both the long and the short splice variants. Selecting for the vector-encoded puromycin resistance gene, we generated four stable lines corresponding to each of the three shRNA constructs (H8, F3, and A4) in addition to a nonsense control cell line (NS). To determine whether protein levels were effectively knocked down by the shRNA constructs, whole-cell lysates from the H8, F3, and A4 lines were compared with lysates from the NS cell line by SDS-PAGE and Western blot analysis with antibodies to various regions of the $\mathrm{ClC} 3$ protein. The example blots shown in Figure 5, $A$ and $B$, were probed with two separate antibodies and demonstrate a significant knockdown of two bands at 116 and 80 $\mathrm{kDa}$ compared with control cells in which a nonsense sequence was transfected. These bands are within the published range of molecular weights for various states of posttranslational modification of the ClC3 isoforms (Huang et al., 2001; Stobrawa et al., 2001). Similar results were consistently observed, and quantification of three independent experiments (Fig. 5B) indicates that ClC3 protein levels were substantially reduced, although not fully eliminated, in the knockdown cell lines.

Having established that these cells expressed reduced levels of protein, we next sought to examine how this change would affect the current profiles of mitotic cells. In the presence or absence of $200 \mu \mathrm{M}$ NPPB, we examined chloride current from cells of either the $\mathrm{ClC} 3$ knockdown or the control lines under whole-cell patchclamp conditions. Mitotic cells were selected based on morphology and nuclear architecture and matched as closely as possible between cell lines (Fig. 6A). Currents were elicited in the presence of $2 \mu \mathrm{M}$ Pax to inhibit $\mathrm{K}^{+}$currents using the voltage step protocol described for Figure 2. As demonstrated by the representative example traces in Figure $6 B$, in nonsense transfected cells, a large proportion of the remaining current could be inhibited by 200 $\mu \mathrm{M}$ NPPB. The subtracted drug-sensitive current in these cells (Fig. 6B, bottom left) displayed outward rectification and time-
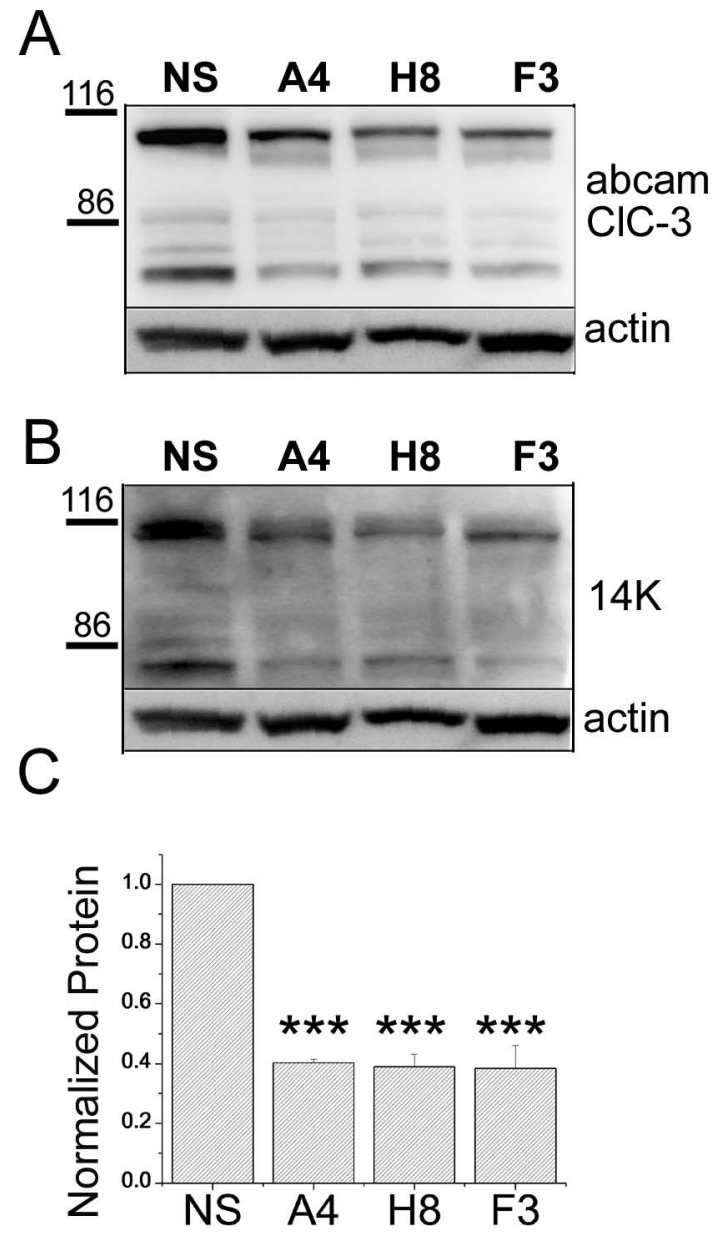

Figure 5. $\mathrm{CIC} 3$ expression is reduced by shRNA constructs. $\boldsymbol{A}, \boldsymbol{B}$, Western blots probed with either Abcam or $14 \mathrm{~K}$ anti-CIC3 and actin as a loading control. $\boldsymbol{A}$, Lysates from control (NS) and CIC3 shRNA-expressing (A4, H8, and F3) cells were probed with Abcam anti-CIC3 antibody. $\boldsymbol{B}$, The blot from $\boldsymbol{A}$ was stripped and then reprobed with the $14 \mathrm{~K}$ antibody. $\boldsymbol{C}$, Densitometry quantification of Abcam anti-CIC3 bands between 116 and $80 \mathrm{kDa}$ normalized to loading controls. $n=3$ independent experiments; one-way ANOVA, $p<0.0001$, Tukey-Kramer post hoc test, ${ }^{* * *} p<0.001$.

dependent inactivation and was both qualitatively and quantitatively similar to the currents present in the untransfected cells (Fig. 2A). In cells that were stably transfected with the shRNA constructs, this current was greatly reduced and often absent (Fig. $6 B$, bottom right). The mean current-voltage ( $I-V)$ relationship of currents from nonsense transfected cells $(n=7)$ compared with the H8 shRNA cell line $(n=7)$ demonstrated in Figure $6 C$ illustrates that NPPB inhibits qualitatively similar, but quantitatively smaller, currents in the mitotic cells of the knock-out cell line. Significantly, the mean current density at $100 \mathrm{mV}$ was decreased $\geq 50 \%$ for all three knockdown lines compared with control cells (H8 control, $7.231 \pm 2.846 \mathrm{pA} / \mathrm{pF}, n=8$ vs H8, $0.5917 \pm$ $0.8665 \mathrm{pA} / \mathrm{pF}, n=9, p=0.0165 ; \mathrm{F} 3$ control, $15.066 \pm 3.856$ $\mathrm{pA} / \mathrm{pF}, n=9$ vs F3, $7.430 \pm 1.726 \mathrm{pA} / \mathrm{pF}, n=9, p=0.0392 ; \mathrm{A} 4$ control, $15.699 \pm 4.812 \mathrm{pA} / \mathrm{pF}, n=10$ vs A4, $4.564 \pm 2.906$ $\mathrm{pA} / \mathrm{pF}, n=8, p=0.0344$; one-tailed $t$ tests). These diminished currents as a result of decreased channel expression implicate $\mathrm{ClC} 3$ as the channel-mediating chloride currents in mitotic cells.

\section{ClC3 associated current is required for efficient PMC}

To determine the effect of knocking down the $\mathrm{ClC} 3$ channel on the ability of cells to undergo PMC, we conducted 2D time-lapse 


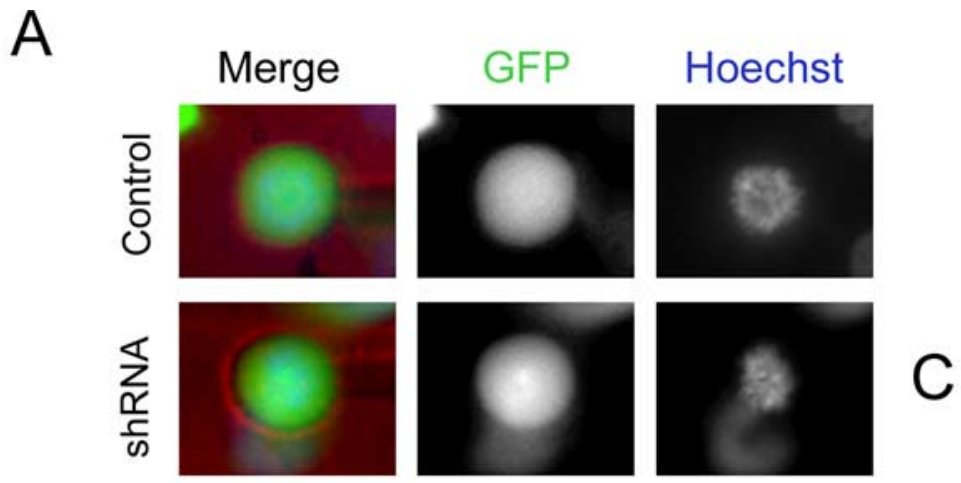

B
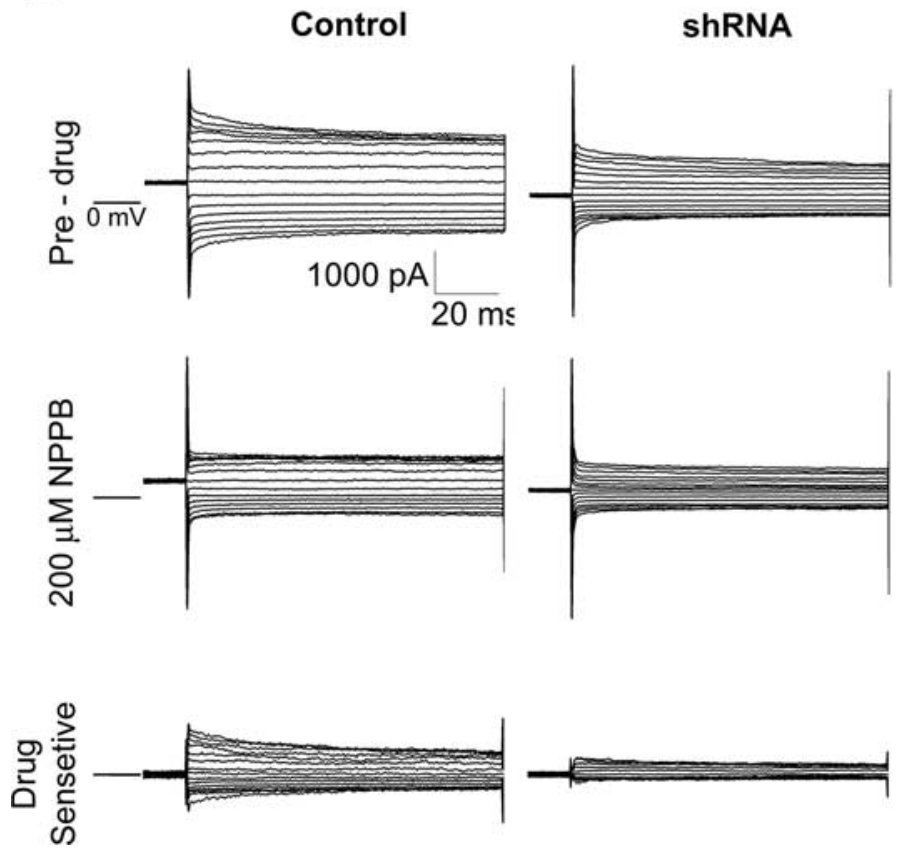

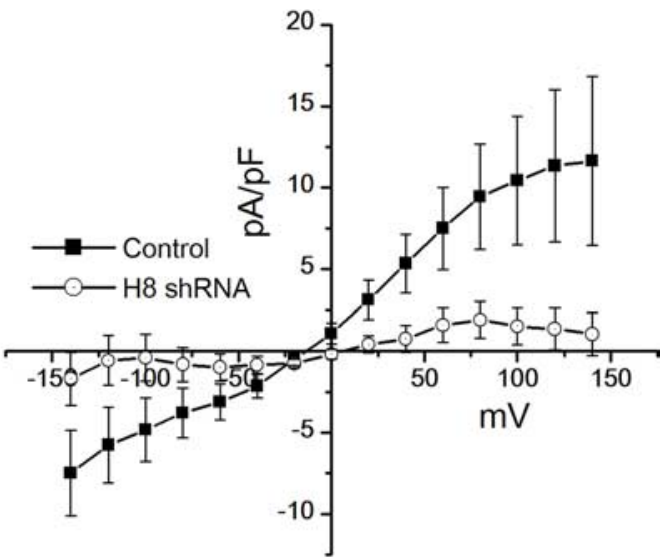

Figure 6. Mitotic chloride currents are reduced by CIC3 shRNA. $\boldsymbol{A}$, Example M phase cells from control and shRNA cell lines. $\boldsymbol{B}$, Example current traces from a control cell (left) and an shRNA-expressing cell (right). Voltage steps were made in the presence (middle traces) or absence (top traces) of $200 \mu \mathrm{m}$ NPPB, and the drug-sensitive current was determined by subtraction (bottom traces). Calibration applies to all traces. C, Current-voltage relationship of the NPPB-sensitive current from control (filled squares) and H8 shRNA (open circles) cells. $n=9$ of each cell type.

experiments in which the control cell line was imaged simultaneously with the shRNA transfected cell lines. Under these conditions, the rate of PMC could be compared in relation to increased or decreased levels of the $\mathrm{ClC} 3$ protein. The time-lapse images in Figure 7A show an example control cell (left) compared with a ClC3 shRNA transfected cell (right) undergoing the process of mitotic cytoplasmic condensation demonstrated by increases in the intensity of the GFP fluorescence. The cytoplasmic condensation occurs rapidly in the control cell with the process of condensation occurring within the course of $40 \mathrm{~min}$. In the shRNA-expressing cell, this process is prolonged and the time required for condensation exceeds $2 \mathrm{~h}$. This was quantified for $n=45$ cell divisions per condition captured from three independent experiments for the H8 shRNA line (circles) compared with control cells (squares) and plotted in Figure $7 B$. It is apparent from these curves that the cytoplasmic GFP in the ClC3 knockdown cells (filled circles) began to condense earlier, at $\sim 120 \mathrm{~min}$ before division, and took longer to reach maximal condensation $\left(F / F_{m}=1\right)$ than in the control cells (filled squares), which condensed within the last $60 \mathrm{~min}$ of the cell cycle. The increase in the time that the cells took to condense is also reflected in a significant decrease (one-way ANOVA, $p=0.0002$ ) in the slope of the change in GFP intensity over time for all three knockdown lines compared with the control line (Fig. 7C). The control cells undergo cytoplasmic condensation at almost twice the rate of the ClC3 shRNA-expressing cells do, indicating that $\mathrm{ClC} 3$ plays a key role in this process. Interestingly, although the loss of $\mathrm{ClC} 3$ causes a significant decrease in the rate of condensation, the volume condensation ultimately does occur, albeit much delayed. This may be explained by an incomplete knockdown of the channel protein, which, on average, leaves $40 \%$ of the original protein remaining. More likely, however, this suggests that a secondary, redundant mechanism for cell condensation exists. Consistent with this notion, a previous paper demonstrated a significant contribution of $\mathrm{KCC} 1$ to $\mathrm{Cl}^{-}$efflux in the context of regulatory volume decrease in osmotically challenged glioma cells (Ernest et al., 2005). Indeed, we were able to reduce the rate of PMC by up to $50 \%$ in the presence of the KCC inhibitor DIOA $[R(+)-$ butylindazone $R$ - $(+)-[(2-n$-butyl-6,7-dichloro-2-cyclopentyl2,3-dihydro-1-oxo-1 $H$-inden-5-yl)oxy] acetic acid] (supple- 
A
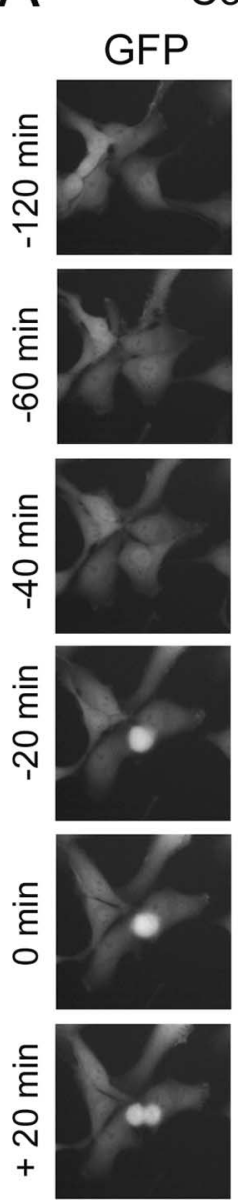

Control
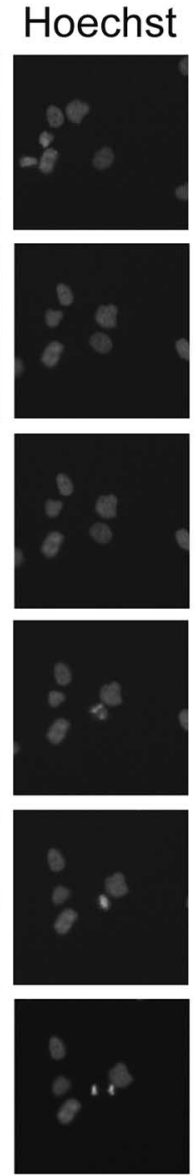

CIC3 shRNA
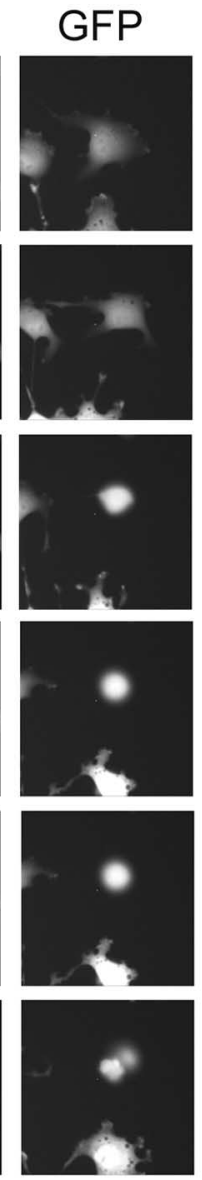
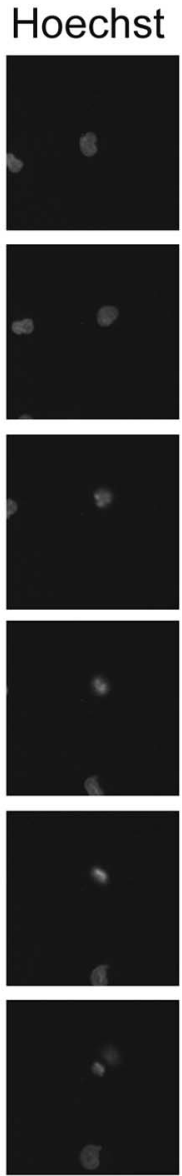

B

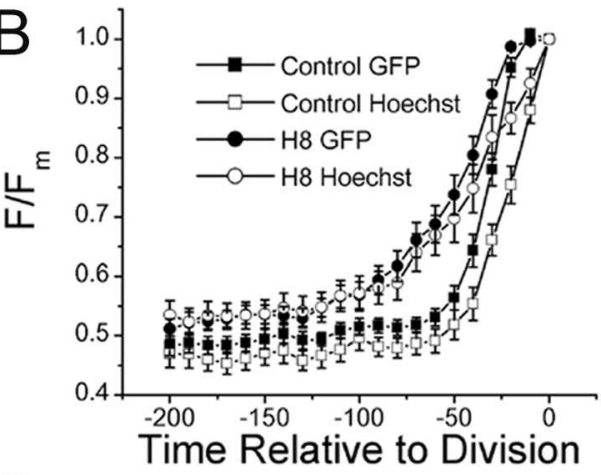

(minutes)
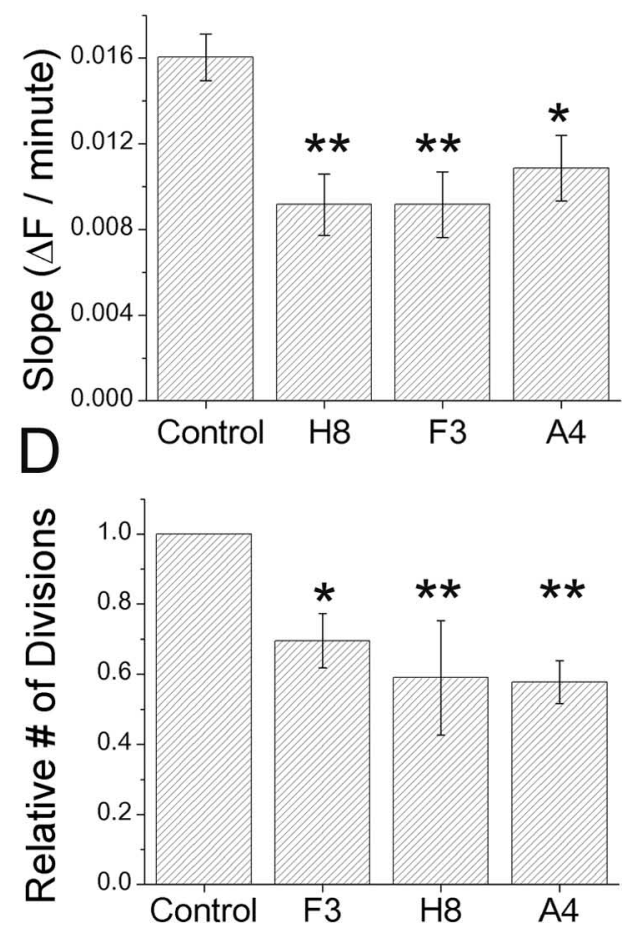

Figure 7. PMC and DNA condensation is impaired by reduced CIC3 expression. A, Images of GFP and Hoechst 33342 fluorescence over time for an example control and an example H8 shRNA cell at $20 \times$ magnification. $\boldsymbol{B}$, Quantification of PMC based on relative GFP fluorescence (filled symbols) and DNA condensation based on relative Hoechst fluorescence (open symbols) for control (squares) and H8 shRNA (circles) cells from three independent experiments. $n=45$ cells each condition. C, Quantification of the rate of PMC in control cells compared with shRNA-expressing cells. The PMC curve was integrated, and the slope at -30 min was determined for $n=69$ cells (control), $n=45$ cells (H8), $n=39$ cells (F3), and $n=45$ cells (A4). The experiment was repeated a minimum of three independent times for each condition. One-way ANOVA, $p<0.001$, Dunnett's post hoc test. $D$, Quantification of the number of cell divisions occurring over a $48 \mathrm{~h}$ period in shRNA-expressing cells compared with controls from three independent experiments. One-way ANOVA, $p<0.01$, Dunnett's post hoc test. ${ }^{*} p<0.05$, ${ }^{* *} p<0.01$ for all graphs.

mental Fig. 1, available at www.jneurosci.org as supplemental material). Because the process of PMC appears to be a critical regulator of the cell cycle, and hence population growth, the fact that multiple mechanisms are in place to ensure a successful volume change and hence cell division is to be expected.

As we have shown in previous work, decreasing the rate of PMC also decreases the rate of the condensation of the DNA into metaphase chromosomes (Habela and Sontheimer, 2007). We therefore analyzed the mitotic DNA condensation by changes in Hoechst intensity (Fig. 7 $A, B$ ) and found that, in the shRNA lines, the $F / F_{m}$ curve for Hoechst intensity (open circles) was slowed to an equal extent as that for the cytoplasmic GFP (filled circles) compared with controls. This is indicative of chromatin condensation not beginning until the onset of cytoplasmic condensation. These results were observed in all three cell lines and, because the result of prolonging any stage of the cell cycle is to increase cell cycle length, we measured the number of divisions occurring during each imaging period. We observed significantly fewer (one-way ANOVA, $p=0.0065$ ) divisions occurring among the knockdown cells (Fig. 7D), indicating a longer time period between divisions and suggesting that the slowed PMC brought about an increase in cell cycle length. This confirms our hypothesis that PMC is linked to DNA condensation and therefore cell cycle progression and supports a role for $\mathrm{ClC} 3$ in this process.

The above data implicate the $\mathrm{ClC} 3$ channel in PMC, yet it does not definitively prove that the size of the membrane currents is deciding the rate of PMC. The immunoprecipitation data and immunostaining in Figure 4 localize intracellular $\mathrm{ClC} 3$ to the region of the mitotic spindle, and loss of activity there in the knockdowns could possibly explain a decreased PMC rate and number of cell divisions. To clarify this, we acutely treated both the control cells and the ClC3 knockdown cells with $200 \mu \mathrm{M}$ NPPB and imaged dividing cells by time-lapse microscopy within the first $4 \mathrm{~h}$ of treatment (Fig. 8). NPPB at this concentration 

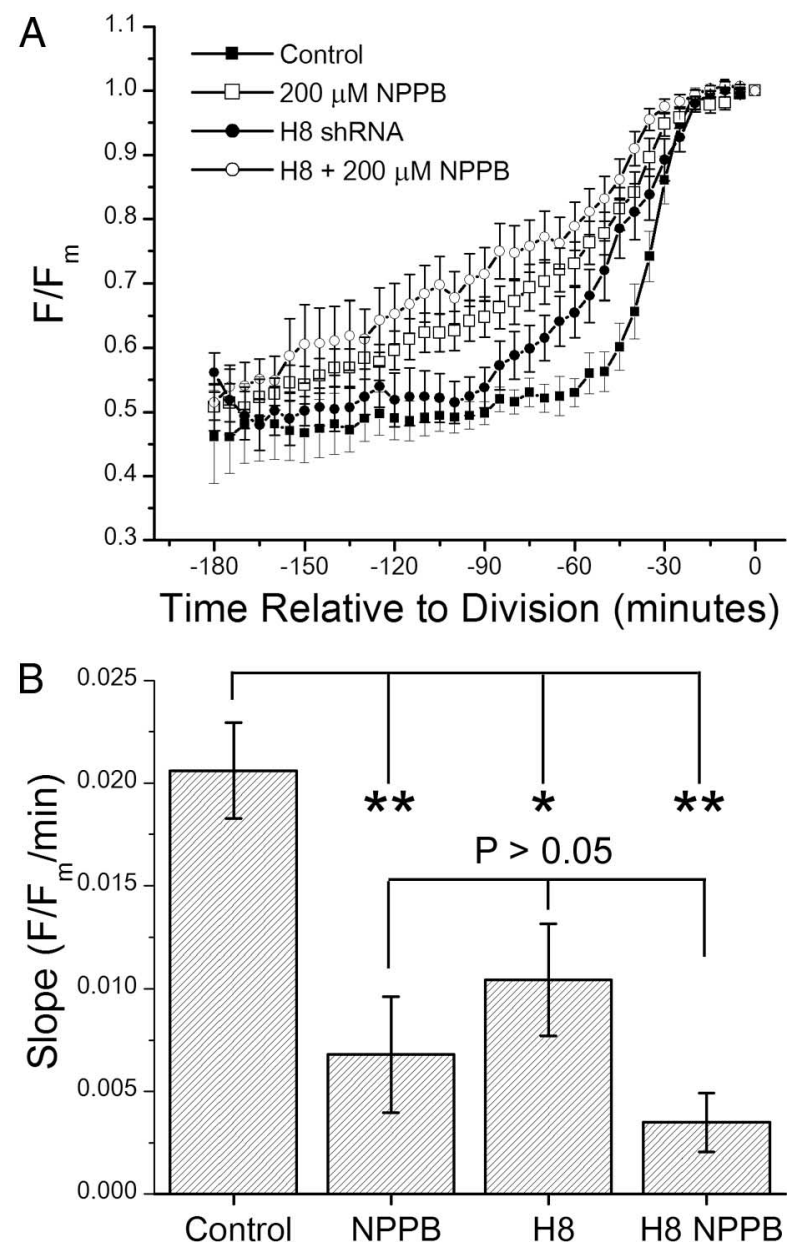

Figure 8. Chloride channel inhibition has similar effects on PMC as CIC3 knockdown. $\boldsymbol{a}$, Mean PMC curves for control cells (squares) and $\mathrm{H} 8$ shRNA cells (circles) treated with $200 \mu \mathrm{m}$ NPPB (open symbols) or vehicle (filled symbols). $\boldsymbol{b}$, Quantification of the rate of PMC at $-30 \mathrm{~min}$ from experiments in $\boldsymbol{a}$. Experiments repeated three independent times. $n=25$ cells for control, $n=$ 23 cells for control treated with NPPB, $n=26$ cells for $\mathrm{H} 8$, and $n=23$ cells for $\mathrm{H} 8$ treated with NPPB. One-way ANOVA, $p<0.01$, Dunnett's post hoc test. ${ }^{*} p<0.05,{ }^{* *} p<0.01$.

should block the mitosis-associated chloride current but have no effect on the overall ClC3 composition of the cells. Analysis of the similarities and differences between NPPB treatment and ClC3 knockdown should therefore differentiate between effects mediated by the channel associated plasma membrane currents and those mediated by other actions of the $\mathrm{ClC} 3$ molecule. Maximal inhibition of the NPPB-sensitive chloride current significantly altered the kinetics of the observed PMC curve in nonsense transfected cells (Fig. 8A, open squares) compared with vehicletreated controls (Fig. $8 A$, filled squares). The PMC curve for the H8 ClC3 shRNA cells (Fig. 8A, filled circles) was also shifted from the nonsense control cells such that the PMC slopes of the NPPBtreated nonsense cells and the control ClC3 shRNA cells were not significantly different (Fig. $8 B$ ). Although there was a trend toward an increased effect at early time points, addition of NPPB to the $\mathrm{H} 8$ cells did not significantly alter this effect. Comparing the NPPB-treated nonsense cells with the NPPB-treated H8 shRNA cells or the $\mathrm{H} 8$ cells alone, there was not a significant difference in the mean slope values (Fig. $8 B$ ). However, all were significantly decreased from the DMSO-treated nonsense transfected controls (Fig. $8 B$ ) (one-way ANOVA, $p=0.0001$, Tukey-Kramer multiple comparisons test). ClC3 may have additional roles in the cell cycle and even in DNA condensation, but these data indicate that the plasma membrane chloride mediated by $\mathrm{ClC} 3$ plays a major role in determining the rate at which these cells undergo PMC and therefore progress through mitosis.

\section{Discussion}

In this study, we established that a cytoplasmic volume condensation accompanying progression through mitosis is a normal part of cell division in both malignant glioma cells and immature cultured astrocytes. This PMC is associated with a chloride current that has the biophysical properties of $\mathrm{ClC} 3$. Involvement of this channel is supported by immunofluorescence localization, and knockdown of $\mathrm{ClC} 3$ in glioma cells not only decreased the chloride currents associated with mitotic cells but slowed PMC, prolonging $\mathrm{M}$ phase and hindering DNA condensation. This mechanistically links $\mathrm{ClC} 3$ to cell division with a specific role in the cytoplasmic and DNA condensation phase of mitosis.

\section{ClC3-mediated chloride currents are involved in mitotic progression of glioma cells}

This is the first study that describes a specific mechanism for chloride channel-modulated progression through $\mathrm{M}$ phase and furthers our knowledge of the functions of $\mathrm{ClC} 3$ in the brain. Although previous studies have analyzed the relative chloride conductance in pharmacologically arrested cells as well as the effect of chloride channel inhibitors on cell cycle arrest (Shen et al., 2000; Doroshenko et al., 2001; Wondergem et al., 2001; Chen et al., 2002, 2007; L. Wang et al., 2002; Zheng et al., 2003; Klausen et al., 2007), the lack of specific inhibitors and the use of population data has caused confusion as to which channels are involved at particular transition points and by what mechanism. As a result, currents with the same profile as $I_{\mathrm{Cl}-\text { Swell }}$ have been implicated in the $G_{0} / G_{1}$ transition, $S$ phase, and mitosis, but it is difficult to distinguish between $\mathrm{I}_{\mathrm{Cl}-\text { Swell }}$ and $\mathrm{I}_{\mathrm{Cl}-\mathrm{ClC} 3}$ based on pharmacology and electrophysiology alone. Complicating the matter further, some controversy surrounds the postulation that ClC3 is the molecular entity behind $\mathrm{I}_{\mathrm{Cl}-\text { Swell }}$ (Duan et al., 1997, 2001; Li et al., 2000; L. Wang et al., 2000; Weylandt et al., 2001; Jin et al., 2003), and there is no consensus as to how to definitively identify either without genetic manipulation.

We demonstrated that an NPPB- and DIDS-sensitive current that is carried as well by bromide as by chloride is increased in mitotic cells compared with bipolar cells. These characteristics established that the current was a chloride current. Furthermore, depolarized RMPs in M phase cells compared with bipolar cells suggests that these channel have enhanced conductance in $M$ phase cells, i.e., are more likely to be open at rest. We relied on shRNA-mediated knockdown to definitively identify $\mathrm{ClC} 3$ as the channel responsible for conducting this current.

ClC3 was originally cloned as a 760 amino acid protein in the rat and shown by Northern blot to be present throughout the body with particularly high levels in the brain (Kawasaki et al., 1994). In situ hybridization demonstrated greatest expression in the hippocampus, olfactory bulb, and cerebellum. Subsequently, a long form containing a 58 amino acid $\mathrm{N}$-terminus insertion was cloned and shown to be the predominant form in the brain (Shimada et al., 2000). Currents elicited from cells expressing the cDNA for these two isoforms demonstrated a permeability sequence of $\mathrm{I}^{-}>\mathrm{Br}^{-}>\mathrm{Cl}^{-}$based on reversal potentials and outward rectification (Kawasaki et al., 1995; Shimada et al., 2000; Matsuda et al., 2008). Additionally, the channel displayed timeand voltage-dependent inactivation (Shimada et al., 2000; Huang et al., 2001). The currents that we observed in M phase cells were consistent with this description and were decreased in the shRNA 
lines. This effect was specific because it was observed with three different sequences. These sequences targeted both long and short form and two bands at 80 and $116 \mathrm{kDa}$ that were consistently present on Western blots of control cells and were knocked down with $\mathrm{ClC} 3$ shRNA. Our results establish ClC3 as the channel behind the chloride conductance in mitotic cells.

\section{PMC and DNA condensation are dependent on ClC3 expression}

The involvement of $\mathrm{ClC} 3$ in the progression of mitosis was established using a single-cell, quantitative imaging technique that allowed us to capture the dynamic changes occurring during mitosis. The rapid volume decrease that we found previously to be functionally linked to DNA condensation was significantly slowed by the shRNA-mediated knockdown of ClC3. The importance of $\mathrm{ClC} 3$ in mitotic progression was further supported by the fact that, in ClC3 shRNA-expressing cells, the condensation of the DNA was hindered to the same extent as the volume decrease.

In D54-MG cells, ClC3 colocalizes with the subcortical actin on the plasma membrane. We also observed, strikingly, that $\mathrm{ClC} 3$ localized to the mitotic spindle (Fig. 4). This association was supported by the coimmunoprecipitation of $\mathrm{ClC} 3$ with $\alpha$-tubulin and suggested the possibility that it is not plasma membrane currents but a direct effect on spindle assembly that mediates the catalysis by the protein of $\mathrm{M}$ phase. To resolve this question, we compared the rate of PMC in control or shRNA cells in the presence or absence of a chloride channel inhibitor. The similarities between the volume condensation curves for shRNAexpressing cells with and without NPPB and control cells treated with NPPB suggests that the primary effect is attributable to plasma membrane currents because chloride channel inhibitors would not be expected to alter intracellular interactions of the protein.

A direct interaction between an $\mathrm{N}$-terminal portion of the $\mathrm{ClC} 3$ protein and clathrin has been demonstrated and is required for internalization (Zhao et al., 2007). Additionally, binding of a C-terminal intracellular portion of $\mathrm{sClC} 3$ to subcortical filamentous actin is required for hypotonic activation of the channel (McCloskey et al., 2007). A potential model for this process, therefore, is that actin rearrangements, occurring at the onset of mitosis, cause $\mathrm{ClC} 3$ to open at the cell membrane. At a membrane potential of $-30 \mathrm{mV}$, opening of the channel causes an efflux of chloride, which draws water out of the cytoplasm. This facilitates membrane collapse as ClC3 undergoes clathrin-mediated endocytosis. The result is a decrease in cytoplasmic water content and membrane surface area. ClC3 has been implicated in endocytosis (Hara-Chikuma et al., 2005), and inhibition of clathrin-mediated endocytosis has been shown to prevent a mitotic reduction in membrane surface area resulting in abnormal spindle morphology and multinucleate cells (Boucrot and Kirchhausen, 2007). Clathrin has been shown to play a structural role in spindle formation (Okamoto et al., 2000; Royle et al., 2005; Royle and Lagnado, 2006), and ClC3 may traffic with clathrin to the spindle. Alternatively, nuclear $\mathrm{ClC} 3$ may facilitate clathrin recruitment. Both scenarios propose a secondary effect of $\mathrm{ClC} 3$ on mitotic progression at the spindles. However, the most direct interpretation of this study is that $\mathrm{ClC} 3$-dependent chloride efflux causes a volume decrease, which in turn facilitates DNA condensation, possibly by decreasing the activation energy for important molecular interactions via molecular crowding.

\section{ClC3 is important in normal as well as pathological states in the brain}

When the long isoform of $\mathrm{ClC} 3$ was cloned in humans, it was determined to be regulated by calcium/calmodulin-dependent kinase II (Reeves and Andreoli, 1992), and a chloride conductance with similar properties was determined to modulate excitability in immature hippocampal neurons from wild-type but not $\mathrm{ClC3}^{-/-}$animals (X. Q. Wang et al., 2006). The importance of $\mathrm{ClC} 3$ to the normal physiology of these neurons is further supported by the fact that, in all knock-out models to date, the primary pathological finding is hippocampal degeneration (Stobrawa et al., 2001; Dickerson et al., 2002; Yoshikawa et al., 2002; Yamamoto-Mizuma et al., 2004). In light of our finding that ClC3 is a modulator of cell cycle progression, it is interesting that this region, which is most affected by its knockdown, is one of the two brain regions in which NSC proliferation continues throughout life.

Self-renewing NSCs with the capacity to differentiate into neurons, astrocytes, and oligodendrocytes have been identified (Gage, 2000; Zhao et al., 2008), and neurogenesis has been shown to occur in both the subventricular zone (Lois and AlvarezBuylla, 1993; Doetsch and Alvarez-Buylla, 1996) and the subgranular zone of the hippocampus (Bayer et al., 1982; Gage, 2000). A growing body of evidence indicates that these cells are the precursors to glioma cells (Ignatova et al., 2002; Hemmati et al., 2003; Rao et al., 2003; Singh et al., 2003; Ma et al., 2008). Although this study does not directly address the relationship between gliomas and NSCs, the implication of the hypothesized NSC origin of glioma is that normal immature cells in the brain and glioma cells may share common mechanisms to enhance their proliferative capacity, and additional investigation should be made into the biophysical alterations that accompany these proliferating cells. We hypothesize that normal immature cells in the brain may use the outwardly directed chloride gradient to drive this rapid volume change as a means to facilitate rapid progression through mitosis as we have shown in glioma cells. Resolving this question will shed light in the normal biology of the brain as well as the mechanisms of cancerous proliferation.

\section{References}

Bayer SA, Yackel JW, Puri PS (1982) Neurons in the rat dentate gyrus granular layer substantially increase during juvenile and adult life. Science 216:890-892.

Borsani G, Rugarli EI, Taglialatela M, Wong C, Ballabio A (1995) Characterization of a human and murine gene (CLCN3) sharing similarities to voltage-gated chloride channels and to a yeast integral membrane protein. Genomics 27:131-141.

Boucrot E, Kirchhausen T (2007) Endosomal recycling controls plasma membrane area during mitosis. Proc Natl Acad Sci U S A 104:7939-7944.

Chen L, Wang L, Zhu L, Nie S, Zhang J, Zhong P, Cai B, Luo H, Jacob TJ (2002) Cell cycle-dependent expression of volume-activated chloride currents in nasopharyngeal carcinoma cells. Am J Physiol Cell Physiol 283:C1313-C1323.

Chen LX, Zhu LY, Jacob TJ, Wang LW (2007) Roles of volume-activated $\mathrm{Cl}-$ currents and regulatory volume decrease in the cell cycle and proliferation in nasopharyngeal carcinoma cells. Cell Prolif 40:253-267.

Dickerson LW, Bonthius DJ, Schutte BC, Yang B, Barna TJ, Bailey MC, Nehrke K, Williamson RA, Lamb FS (2002) Altered GABAergic function accompanies hippocampal degeneration in mice lacking ClC-3 voltagegated chloride channels. Brain Res 958:227-250.

Doetsch F, Alvarez-Buylla A (1996) Network of tangential pathways for neuronal migration in adult mammalian brain. Proc Natl Acad Sci U S A 93:14895-14900.

Doroshenko P, Sabanov V, Doroshenko N (2001) Cell cycle-related changes in regulatory volume decrease and volume-sensitive chloride conductance in mouse fibroblasts. J Cell Physiol 187:65-72. 
Duan D, Winter C, Cowley S, Hume JR, Horowitz B (1997) Molecular identification of a volume-regulated chloride channel. Nature 390:417-421.

Duan D, Zhong J, Hermoso M, Satterwhite CM, Rossow CF, Hatton WJ, Yamboliev I, Horowitz B, Hume JR (2001) Functional inhibition of native volume-sensitive outwardly rectifying anion channels in muscle cells and Xenopus oocytes by anti-ClC-3 antibody. J Physiol 531:2-44.

Ernest NJ, Weaver AK, Van Duyn LB, Sontheimer HW (2005) Relative contribution of chloride channels and transporters to regulatory volume decrease in human glioma cells. Am J Physiol Cell Physiol 288:C1451-C1460.

Fan X, Salford LG, Widegren B (2007) Glioma stem cells: evidence and limitation. Semin Cancer Biol 17:214-218.

Gage FH (2000) Mammalian neural stem cells. Science 287:1433-1438.

Habela CW, Sontheimer H (2007) Cytoplasmic volume condensation is an integral part of mitosis. Cell Cycle 6:1613-1620.

Hamill OP, Marty A, Neher E, Sakmann B, Sigworth FJ (1981) Improved patch-clamp techniques for high-resolution current recording from cells and cell-free membrane patches. Pflugers Arch 391:85-100.

Hara-Chikuma M, Yang B, Sonawane ND, Sasaki S, Uchida S, Verkman AS (2005) ClC-3 chloride channels facilitate endosomal acidification and chloride accumulation. J Biol Chem 280:1241-1247.

Hemmati HD, Nakano I, Lazareff JA, Masterman-Smith M, Geschwind DH, Bronner-Fraser M, Kornblum HI (2003) Cancerous stem cells can arise from pediatric brain tumors. Proc Natl Acad Sci U S A 100:15178-15183.

Huang P, Liu J, Di A, Robinson NC, Musch MW, Kaetzel MA, Nelson DJ (2001) Regulation of human CLC-3 channels by multifunctional $\mathrm{Ca}^{2+}$ / calmodulin-dependent protein kinase. J Biol Chem 276:20093-20100.

Ignatova TN, Kukekov VG, Laywell ED, Suslov ON, Vrionis FD, Steindler DA (2002) Human cortical glial tumors contain neural stem-like cells expressing astroglial and neuronal markers in vitro. Glia 39:193-206.

Jin NG, Kim JK, Yang DK, Cho SJ, Kim JM, Koh EJ, Jung HC, So I, Kim KW (2003) Fundamental role of ClC-3 in volume-sensitive $\mathrm{Cl}-$ channel function and cell volume regulation in AGS cells. Am J Physiol Gastrointest Liver Physiol 285:G938-G948.

Jorgensen P, Tyers M (2004) How cells coordinate growth and division. Curr Biol 14:R1014-R1027.

Kakazu Y, Akaike N, Komiyama S, Nabekura J (1999) Regulation of intracellular chloride by cotransporters in developing lateral superior olive neurons. J Neurosci 19:2843-2851.

Kawasaki M, Uchida S, Monkawa T, Miyawaki A, Mikoshiba K, Marumo F, Sasaki S (1994) Cloning and expression of a protein kinase c-regulated chloride channel abundantly expressed in rat brain neuronal cells. Neuron 12:597-604.

Kawasaki M, Suzuki M, Uchida S, Sasaki S, Marumo F (1995) Stable and functional expression of the CIC-3 chloride channel in somatic cell lines. Neuron 14:1285-1291.

Klausen TK, Bergdahl A, Hougaard C, Christophersen P, Pedersen SF, Hoffmann EK (2007) Cell cycle-dependent activity of the volume- and $\mathrm{Ca}^{2+}$-activated anion currents in Ehrlich lettre ascites cells. J Cell Physiol 210:831-842.

Kuner T, Augustine GJ (2000) A genetically encoded ratiometric indicator for chloride: capturing chloride transients in cultured hippocampal neurons. Neuron 27:447-459.

Li X, Shimada K, Showalter LA, Weinman SA (2000) Biophysical properties of ClC-3 differentiate it from swelling-activated chloride channels in Chinese hamster ovary-K1 cells. J Biol Chem 275:35994-35998.

Lois C, Alvarez-Buylla A (1993) Proliferating subventricular zone cells in the adult mammalian forebrain can differentiate into neurons and glia. Proc Natl Acad Sci U S A 90:2074-2077.

Ma YH, Mentlein R, Knerlich F, Kruse ML, Mehdorn HM, Held-Feindt J (2008) Expression of stem cell markers in human astrocytomas of different WHO grades. J Neurooncol 86:31-45.

Mao J, Chen L, Xu B, Wang L, Li H, Guo J, Li W, Nie S, Jacob TJ, Wang L (2008) Suppression of ClC-3 channel expression reduces migration of nasopharyngeal carcinoma cells. Biochem Pharmacol 75:1706-1716.

Matsuda JJ, Filali MS, Volk KA, Collins MM, Moreland JG, Lamb FS (2008) Overexpression of CLC-3 in HEK293T cells yields novel currents that are pH dependent. Am J Physiol Cell Physiol 294:C251-C262.

McCloskey DT, Doherty L, Dai YP, Miller L, Hume JR, Yamboliev IA (2007) Hypotonic activation of short $\mathrm{ClC} 3$ isoform is modulated by direct interaction between its cytosolic C-terminal tail and subcortical actin filaments. J Biol Chem 282:16871-16877.

Okamoto CT, McKinney J, Jeng YY (2000) Clathrin in mitotic spindles. Am J Physiol Cell Physiol 279:C369-C374.
Oliver TG, Wechsler-Reya RJ (2004) Getting at the root and stem of brain tumors. Neuron 42:885-888.

Olsen ML, Schade S, Lyons SA, Amaral MD, Sontheimer H (2003) Expresssion of voltage-gated chloride channels in human glioma cells. J Neurosci 23:5572-5582.

Ransom CB, Sontheimer H (2001) BK channels in human glioma cells. J Neurophysiol 85:790-803.

Rao G, Pedone CA, Coffin CM, Holland EC, Fults DW (2003) c-Myc enhances sonic hedgehog-induced medulloblastoma formation from nestin-expressing neural progenitors in mice. Neoplasia 5:198-204.

Reeves WB, Andreoli TE (1992) Renal epithelial chloride channels. Annu Rev Physiol 54:29-50.

Royle SJ, Lagnado L (2006) Trimerisation is important for the function of clathrin at the mitotic spindle. J Cell Sci 119:4071-4078.

Royle SJ, Bright NA, Lagnado L (2005) Clathrin is required for the function of the mitotic spindle. Nature 434:1152-1157.

Sanai N, Alvarez-Buylla A, Berger MS (2005) Neural stem cells and the origin of gliomas. N Engl J Med 353:811-822.

Shen MR, Droogmans G, Eggermont J, Voets T, Ellory JC, Nilius B (2000) Differential expression of volume-regulated anion channels during cell cycle progression of human cervical cancer cells. J Physiol 529:385-394.

Shimada K, Li X, Xu G, Nowak DE, Showalter LA, Weinman SA (2000) Expression and canalicular localization of two isoforms of the clc- 3 chloride channel from rat hepatocytes. Am J Physiol Gastrointest Liver Physiol 279:G268-G276.

Singh SK, Clarke ID, Terasaki M, Bonn VE, Hawkins C, Squire J, Dirks PB (2003) Identification of a cancer stem cell in human brain tumors. Cancer Res 63:5821-5828.

Stobrawa SM, Breiderhoff T, Takamori S, Engel D, Schweizer M, Zdebik AA, Bösl MR, Ruether K, Jahn H, Draguhn A, Jahn R, Jentsch TJ (2001) Disruption of ClC-3, a chloride channel expressed on synaptic vesicles, leads to a loss of the hippocampus. Neuron 29:185-196.

von Weikersthal SF, Barrand MA, Hladky SB (1999) Functional and molecular characterization of a volume-sensitive chloride current in rat brain endothelial cells. J Physiol 516:75-84.

Wang GL, Wang XR, Lin MJ, He H, Lan XJ, Guan YY (2002) Deficiency in ClC-3 chloride channels prevents rat aortic smooth muscle cell proliferation. Circ Res 91:E28-E32.

Wang L, Chen L, Jacob TJ (2000) The role of clc-3 in volume-activated chloride currents and volume regulation in bovine epithelial cells demonstrated by antisense inhibition. J Physiol 524:63-75.

Wang L, Chen L, Zhu L, Rawle M, Nie S, Zhang J, Ping Z, Kangrong C, Jacob TJ (2002) Regulatory volume decrease is actively modulated during the cell cycle. J Cell Physiol 193:110-119.

Wang XQ, Deriy LV, Foss S, Huang P, Lamb FS, Kaetzel MA, Bindokas V, Marks JD, Nelson DJ (2006) CLC-3 channels modulate excitatory synaptic transmission in hippocampal neurons. Neuron 52:321-333.

Weylandt KH, Valverde MA, Nobles M, Raguz S, Amey JS, Diaz M, Nastrucci C, Higgins CF, Sardini A (2001) Human ClC-3 is not the swellingactivated chloride channel involved in cell volume regulation. J Biol Chem 276:17461-17467.

Wondergem R, Gong W, Monen SH, Dooley SN, Gonce JL, Conner TD, Houser M, Ecay TW, Ferslew KE (2001) Blocking swelling-activated chloride current inhibits mouse liver cell proliferation. J Physiol 532:3-72.

Yamamoto-Mizuma S, Wang GX, Liu LL, Schegg K, Hatton WJ, Duan D, Horowitz TL, Lamb FS, Hume JR (2004) Altered properties of volumesensitive osmolyte and anion channels (VSOACs) and membrane protein expression in cardiac and smooth muscle myocytes from Clcn3-/mice. J Physiol 557:439-456.

Yoshikawa M, Uchida S, Ezaki J, Rai T, Hayama A, Kobayashi K, Kida Y, Noda M, Koike M, Uchiyama Y, Marumo F, Kominami E, Sasaki S (2002) CLC-3 deficiency leads to phenotypes similar to human neuronal ceroid lipofuscinosis. Genes Cells 7:597-605.

Zhao C, Deng W, Gage FH (2008) Mechanisms and functional implications of adult neurogenesis. Cell 132:645-660.

Zhao Z, Li X, Hao J, Winston JH, Weinman SA (2007) The ClC-3 chloride transport protein traffics through the plasma membrane via interaction of an N-terminal dileucine cluster with clathrin. J Biol Chem 282:29022-29031.

Zheng YJ, Furukawa T, Tajimi K, Inagaki N (2003) Cl- channel blockers inhibit transition of quiescent (G0) fibroblasts into the cell cycle. J Cell Physiol 194:376-383. 